\title{
Explaining Constitutional Review in New Democracies: The Case of Taiwan
}

Nuno Garoupa

ngaroup@gmu.edu

Veronica Grembi

Shirley Ching-Ping Lin

Follow this and additional works at: https://scholarship.law.tamu.edu/facscholar

Part of the Law Commons

\section{Recommended Citation}

Nuno Garoupa, Veronica Grembi \& Shirley C. Lin, Explaining Constitutional Review in New Democracies: The Case of Taiwan, 20 Pac. Rim L. \& Pol'y J. 1 (2011).

Available at: https://scholarship.law.tamu.edu/facscholar/503

This Article is brought to you for free and open access by Texas A\&M Law Scholarship. It has been accepted for inclusion in Faculty Scholarship by an authorized administrator of Texas A\&M Law Scholarship. For more information, please contact aretteen@law.tamu.edu. 


\title{
EXPLAINING CONSTITUTIONAL REVIEW IN NEW DEMOCRACIES: THE CASE OF TAIWAN
}

\author{
Nuno Garoupa, Veronica Grembi and Shirley Ching-ping Lin ${ }^{\dagger}$
}

\begin{abstract}
This paper extends the empirical analysis of the determinants of judicial behavior by considering the Taiwanese case. Taiwan is a particularly interesting case because the establishment and development of constitutional review corresponds to a political transition from an authoritarian regime dominated by one party to an emerging democracy. We test the attitudinal hypothesis by making use of a new dataset of ninetyseven decisions issued by the Taiwanese constitutional court in the period between 1988 and 2008. The attitudinal hypothesis is that the Taiwanese constitutional judges respond to party interests, either because their preferences coincide with the appointer or because they want to exhibit loyalty to the appointer. Our econometric analysis does not provide strong evidence for the attitudinal hypothesis. However, we provide an explanation. Faced with a transition from a one-party political regime to a democracy, the Taiwanese Grand Justices needed to assert their independence from the other branches of government and gain credibility, thus dissenting more often, periodically and individually voting against the interests of the dominant party.
\end{abstract}

\section{INTRODUCTION}

Judicial behavior has become an important field of study for legal economists, political scientists, and lawyers. ${ }^{1}$ At the same time, the importance and role of constitutional courts has attracted the attention of scholars and policymakers. Any theory of constitutional review requires a significant understanding of judicial behavior. In fact, the appropriate design of constitutional review plays an important role in political stability,

$\dagger$ Nuno Garoupa, UIUC College of Law; Veronica Grembi, Università Cattolica del Sacro Cuore (Milan); Shirley Ching-ping Lin, SJD Candidate, Northwestern University School of Law. Address correspondence to Nuno Garoupa at the University of Illinois College of Law, 504 E. Pennsylvania Avenue, Champaign, Illinois 61820, United States of America, or to ngaroupa@illinois.edu. The authors are grateful to Wen-cheng Chang, Shao Dan, Ted Eisenberg, Tom Ginsburg, K. C. Huang, David Law, Tom Miles, Mark Ramseyer, Lydia Brashear Tiede, Tay-sheng Wan and the participants at the Fifth Conference of Empirical Legal Studies (USC, 2009) for their useful comments and suggestions. Nuno Garoupa acknowledges financial support by FCT, PPCDT/JUR/55752/2006. We are also grateful to Rachel Jo-yu Chen, Tzu-Te Wen and Jessie Chien-yu Hsu for superb research assistantship. And we are grateful to Caroline Belloff and Roya H. Samarghandi for reviewing the paper. The usual disclaimers apply.

I For further discussion, see Saul Brenner \& Harold J. Spaeth, Ideological Position as a Variable in the Authoring of Dissenting Opinions on the Warren and Burger Courts, 16 AM. POL. Q. 317, 317-328 (1988); Albert D. Cover \& Jeffrey A. Segal, Ideological Values and the Votes of U.S. Supreme Court Justices, 83 AM. POL. SCI. REv. 557, 557-565 (1989); LeE EPSTEIN \& JACK KNIGHT, THE CHOICES JuSTICES Make (CQ Press 1997); Jeffrey A. Segal \& Harold J. SPaeth, The Supreme Court and the attitudinal Model Revisited (Cambridge Univ. Press 2002); Thomas G.. Hansford \& James F. SPRIGgS, II, THe Politics of Precedent On THE U.S. SuPReME Court (Princeton Univ. Press 2008). 
consolidation of democracy, and economic growth. ${ }^{2}$ Judicial decisionmaking in a constitutional court is the result of multiple variables, including: 1) personal attributes, ${ }^{3}$ 2) attitudes (including policy preferences in the relevant dimensions), 3) peer pressure and intra-court interaction (a natural pressure for consensus and court reputation; a common objective for the constitutional court to achieve supremacy over competing political and judicial powers), and 4) party politics (loyalty to the appointer) within a given constitutional and doctrinal environment (for example, more or less formalist). ${ }^{4}$ The relative importance of these variables varies across explanatory theories. A pure formalist does not recognize personal attributes or ideological preferences as a powerful explanatory variable of judicial behavior. $^{5}$ A supporter of the attitudinal model does not recognize the institutional and doctrinal environment as a serious constraint to preferences. $^{6}$ A supporter of the principal-agent model sees intra-court as well as competing powers derived from government interaction as a major limitation to ideological advancements of the agent. ${ }^{7}$

Furthermore, some explanatory variables may have multiple interpretations. For example, there are at least two possible explanations for the conformity between constitutional judges and party interests. First, constitutional judges often exhibit the same preferences as the political party that they affiliate with. Second, when the constitutional judges do not have lifetime appointments, they might want to maintain good relations with the party that selected them in the hope of securing future appointments to the court or elsewhere (regardless of whether the terms are renewable or not). Both reasons suggest that judges are incentivized by their political biases

2 For a good introduction, see Tom Ginsburg, Economic Analysis and Design of Constitutional Courts, 3 THEORETICAL INQUIRIES IN L. 49 (2002) [hereinafter Ginsburg, Economic Analysis].

For judicial preferences, see Frank H. Easterbrook, What's So Special about Judges?, 61 U. CoLo L. REv. 773 (1990); Richard A. Posner, What Do Judges and Justices Maximize? (The Same Thing Everybody Else Does), 3 SUP. Cr. ECON. REV. 1 (1993) [hereinafter Posner, What Do Judges and Justices Maximize?]; Richard A. Posner, Judicial Behavior and Performance: An Economic Approach, 32 FLA. ST. U. L. Rev. 1259 (2005) [hereinafter Posner, Judicial Behavior]; Laurence Baum, What Judges Want. Judges' Goals and Judicial Behavior, 47 POL. RES. Q. 749 (1994); Frederick Schauer, Incentives, Reputation, and the Inglorious Determinants of Judicial Behavior, 68 U. CNN. L. REV. 615 (2000).

${ }_{4}$ See, e.g., Lee Epstein \& Tracey E. George, On the Nature of Supreme Court Decision Making, 86 AM. POL. SCI. REv. 323 (1992); Charles M. Cameron \& Jeffrey R. Lax, Bargaining and Opinion Assignment on the U.S. Supreme Court, 23 J. L. ECON. \& ORG. 276 (2007).

5 Id.

6 Id.

7 See sources cited supra note 1; see also Lee Epstein, Jeffrey Allan Segal \& Harold J. Spaeth, The Norm of Consensus on the U.S. Supreme Court, 45 AM. J. POL. SCI. 362 (2001); Brian Goff, Supreme Court Consensus and Dissent: Estimating the Role of the Selection Screen, 127 PUB. CHOICE 367 (2006); JOHN Henry Merryman \& Rogelio PÉrez-Perdomo, The Civil Law Tradition (Stanford Univ. Press 2007) (discussing pressure for consensus in the civil law tradition). 
and are not fully insulated from the political system. However, the basis for those political biases differs; the biases can be rooted in personal preferences or in strategic opportunism.

It is no surprise that the process of recruitment and appointment of judges is a major variable in the design of constitutional courts. Some scholars assert that, as expected, overly party-oriented mechanisms are especially bad for independent judicial review, ${ }^{8}$ but are quite likely to smooth conflicts with other bodies of governance. Cooperative mechanisms that require a supermajority deliver consensual constitutional courts that are more deliberative than active lawmakers. ${ }^{9}$

These issues cannot be settled without solid empirical analysis. Although the U.S. Supreme Court has been the focus of much attention by legal scholars, ${ }^{10}$ empirical debates about other constitutional courts are almost nonexistent, with notable exceptions. ${ }^{11}$ This paper extends the empirical analysis of judicial behavior by analyzing the Taiwanese case.

8 For theories of judicial independence, see William M. Landeis \& Richard Posner, The Independent Judiciary in an Interest-Group Perspective, 18 J. L. \& ECON. 875 (1975); Richard A. Epstein, The Independence of Judges: The Uses and Limitations of Public Choice, 1990 BRIGHAM Young UNIV. L. REV. 827; J. Mark Ramseyer, The Puzzling (In)dependence of Courts, 23 J. LEGAL STUD. 721 (1994).

9 See Tom Ginsburg, Judicial ReVIEW in New Democracies: Constitutional Courts in ASIAN CASES 42 (Cambridge Univ. Press 2003) [hereinafter GINSBURG, JUdicial REVIEW].

${ }_{10}$ See e.g. sources cited supra notes $1 \& 7$.

11 On Japan and the Japanese Supreme Court, see J. MARK RAMSEYER \& ERIC B. RASMUSEN, MEASURING JUdiCIAL INDEPENDENCE: THE POLITICAL ECONOMY OF JUDGING IN JAPAN (Univ. of Chicago Press 2003); J. Mark Ramseyer \& Eric B. Rasmusen, The Case for Managed Judges: Learning from Japan after the Political Upheaval of 1993, 154 U. PA. L. REv. 1879 (2006). On Canada, see Benjamin Alarie \& Andrew Green, Should They All Just Get Along? Judicial Ideology, Collegiality, and Appointments to the Supreme Court of Canada, 58 UNIV. NEW BRUNSWICK L. J. 73 (2008); Benjamin Alarie \& Andrew Green , Policy Preference Change and Appointments to the Supreme Court of Canada, 47 OsGoodE HALL L. J. 1 (2009). On Australia, see Paresh Kumar Narayan \& Russell Smyth, Hail to the Chief! Leadership and Structural Change in the Level of Consensus on the High Court of Australia, 1 J. EMPIRICAL LEGAL STUD. 399 (2004); Paresh Kumar Narayan \& Russell Smyth, What Explains Dissent on the High Court of Australia? An Empirical Assessment Using a Cointegration and Error Correction Approach, $4 \mathrm{~J}$. EMPIRICAL LEGal StUd. 401 (2007). On Germany, see Martin R. Schneider, Judicial Career Incentives and Court Performance: An Empirical Study of the German Labour Courts of Appeal, 20 EuR. J. L. \& ECON. 127 (2005); GEORG VANBERG, THE POLITICS OF CONSTITUTIONAL REVIEW IN GERMANY (Cambridge Univ. Press 2005). On Italy, see Albert Breton \& Angela Fraschini, The Independence of the Italian Constitutional Court, 14 CONST. POL. ECON. 319 (2003); Nadio Fiorino, Fabio Padovano \& Grazia Sgarra, The Determinants of Judicial Independence: Evidence from the Italian Constitutional Court (1956-2002), 163 J. INSTITUTIONAL \& THEORETICAL ECON. 683 (2007). On France, see RAPHAEL FRANCK, WhEN JUDGES RULE ON THE VALIDITY OF ELECTIONS, ARE THEY PARTISAN? AN EXAMINATION OF THE DECISIONS OF THE FRENCH CONSTITUTIONAL COURT, 1958-2005 (2008) [hereinafter FRANCK, WHEN JUDGES RULE]; Raphael Franck, Judicial Independence under a Divided Polity: A Study of the Rulings of the French Constitutional Court, 1959-2006, 25 J. LAW, ECON. \& ORG. 262 (2009). On Portugal, see Sofia Amaral Garcia, Nuno Garoupa \& Veronica Grembi, Judicial Independence and Party Politics in the Kelsenian Constitutional Courts: the Case of Portugal (July 7, 2008) (U. Ill. L. \& Econ. Res. Paper No. LE08-2,), available at http://papers.ssm.com/sol3/papers.cfm?abstract_id=1156281 (last visited Nov. 16, 2010) [hereinafter Garcia, Garoupa \& Grembi, 2008]; Sofia Amaral Garcia, Nuno Garoupa \& Veronica Grembi, 
Taiwan is a particularly interesting case because the establishment and development of constitutional review corresponds to a transition from an authoritarian regime to an emerging democracy. ${ }^{12}$ Other scholars have identified the case of Taiwan as one of success where the constitutional court has increasingly assumed a relevant role, but at the same time has been able to avoid excessive backlash from the political actors. ${ }^{13}$

The Taiwanese Constitution ("Constitution" or "ROC Constitution") is one of the oldest present constitutions in the world. Similarly, the Taiwanese constitutional court (also known as the "Council of Grand Justices" or "Council") almost predates all the other specialized constitutional courts. Although composition and competences have been reformed in the last fifty years, the Taiwanese constitutional court is not a new product, as are its counterparts in many third-wave democracies (for example, Spain, Portugal, Eastern European countries, and Chile), but an institution that has prevailed throughout the authoritarian period and the more recent emerging democracy. The age and the role of the Taiwanese constitutional court make it quite different from other constitutional courts around the world, and therefore very unique for empirical analysis.

In addition to the above-mentioned characteristics, the Council of Grand Justices follows the centralized model (also referred to as the "Austrian," "Kelsenian," or "European" model) of constitutional review ${ }^{14}$ rather than the decentralized review system of the United States or Japan. The Council was founded in China in 1948 and retreated with the ROC

\footnotetext{
Judicial Independence and Party Politics in the Kelsenian Constitutional Courts: the Case of Portugal, $6 \mathrm{~J}$. EMPIRICAL LEGAL STUD. 383 (2009) [hereinafter Garcia, Garoupa \& Grembi, 2009]. On Spain, see Nuno Garoupa, Fernando Gomez Pomar \& Veronica Grembi, Judging under Political Pressure: An Empirical Analysis of the Constitutional Review Vote in the Spanish Constitutional Court (2009) (unpublished mimeograph, on file with authors).

12 On other transitions, see GRETCHEN HELMKE, COURTS UNDER CONSTRAINTS: JUDGES, GENERALS, and Presidents In ARgentina (Cambridge Univ. Press 2004); LiSA HILbINK, Judges Beyond Polttics in Democracy and DictatorshIP: Lessons from ChILE (Cambridge Univ. Press 2007); R. BILl Chávez, The Rule of law in Nascent Democracies: Judicial Politics in ARgentina (Stanford Univ. Press 2004)

13 See GINSBURG, JUDICIAL REVIEW, supra note 9, at 106.

14 See VICKI C. JaCkSON \& Mark Tushnet, Comparative CONSTITUTIONAL LAW 465-66 (Foundation Press 2d ed. 2006). The Council portrays itself as a "model similar to the German and Austrian system." See Sifayuan Shizi Di 419 [nterpretation No. 419] (Constitutional Court, Dec. 31, 1996) (Taiwan). The majority opinions of the Judicial Yuan Interpretations have been translated into English and are available at the web site of the Judicial Yuan, at http:/www.judicial.gov.tw/CONSTITUTIONALCOURT/en/p03.asp (last visited Sept. 10, 2010). No separate reference to the web site or transliterated Chinese case names will be provided hereafter in this article.
} 
government to Taiwan in $1949 .^{15}$ Prior to 2003 , the Council was composed of seventeen Grand Justices who were appointed by the President with approval of the Control Yuan (1948-1992) or the National Assembly (1992$2000),{ }^{16}$ and served renewable terms of nine years. The Presidents of the Judicial Yuan presided over the Council meetings, even though they were not Grand Justices at the time. ${ }^{17}$ Now the number of Grand Justices is reduced to fifteen, and the President and the Vice President of the Judicial Yuan must be Grand Justices at the same time. Except for the eight Justices appointed in 2003 serving for four years, the Justices are now appointed by the President with the majority consent of the Legislative Yuan, and serve non-renewable terms of eight years. ${ }^{18}$ Since half of the Justices are renewed every four years, theoretically, each President has the chance to appoint seven or eight Justices during his or her four-year term.

The importance of the Council and the significant role it plays in Taiwan makes it an interesting framework to pursue an empirical analysis of judicial behavior. Our research tested the attitudinal model in the Council of Grand Justices in the period between 1988 and 2008. We hypothesized that the Taiwanese constitutional judges respond to party interests, either because their preferences coincide with the appointer or because they want to exhibit loyalty to the appointer. Given the disproportional influence of the Chinese Nationalist Party ("KMT" or "Kuomintang") in the appointment process throughout most of the period, we expected the Grand Justices appointed by KMT Presidents (in 1985, 1994 and 1999) to favor KMT interests. At the same time, we expected the Grand Justices appointed by the President supported by the Democratic Progressive Party ("DPP"), the major opposition to KMT, (in 2003 and 2007) to disfavor KMT interests. However, given that the opposition never actually dominated the relevant confirming body (i.e. the Control Yuan, the National Assembly, or the

15 See Y. S. Weng, Woguo Shixianzhidu zhi Tezheng yu Zhanwang (The Features and Prospects of the Republic of China (ROC) Constitutional Review System], in SIFAYUAN DAFAGUAN SHIEXIAN WUSHIZHOUNIAN JINIAN LUNWENI [ESSAYS IN MEMORY OF THE FIFTIETH ANNIVERSARY OF CONSTITUTIONAL. INTERPRETATIONS BY THE GRAND JUSTICES OF THE JUDICIAL YUAN] 297 (Dept. of Clerks for the Justices of the Constitutional Court ed. 2000).

16 Sifayuan Zhuzhifa [The Organic Act of the Judicial Yuan] [hereinafter "OAJY"] art. 3 (1947) (amended 2001), available at http://www.judicial.gov.tw/constitutionalcourt/p07_2.asp?lawno=81 (last visited Apr. 8, 2009); see also MINGUo XIANFA (1947); Interpretation No. 541 (Apr. 4, 2002), Judicial Yuan Interpretations, supra note 14.

${ }_{17}$ See OAJY, supra note 16, at arts. 3 (1), 3 (2), 5 (2); see also Thomas Weishing Huang, Judicial Activism in the Transitional Polity: The Council of Grand Justices in Taiwan, 19 TEMP. INT'L \& COMP. L. J. 1, 6 (2005) [hereinafter Huang, Judicial Activism].

18 See Minguo XIANFA, Additional Articles (2000); see also Minguo XIANFA ant. 5. Moreover, it is noteworthy that the Justices who serve as president and vice president of the Judicial Yuan do not enjoy the guarantee of an eight-year term. MINGUO XIANFA art. 5(2). 
Legislative Yuan), we expected the second effect (alignment between the interests of the opposition and the voting patterns of justices appointed by the DPP President) to be less significant than the first effect (alignment between the interests of the KMT and the voting patterns of justices appointed by the KMT Presidents). Under this hypothesis, the affiliation of the Grand Justices, as measured by the President who appointed them, is a good predictor of their voting patterns in the court. ${ }^{19}$

The appointment mechanism, as mentioned above, is heavily dominated by the President and the political parties of the relevant confirming body (under the influence of the KMT and its allies). In this case, the choice of Grand Justices should correspond to the preferences of the appointing President given the position of the Control Yuan, the National Assembly or the Legislative Yuan (which is supposed to pose little problem for the KMT Presidents but could exert certain influence in the case of DPP President Chen). Hence, we expected preferences to largely coincide. Moreover, the Grand Justices have limited tenure and before 2003, there was the possibility of reappointment. Thus, we also expected that these two factors would reinforce the possibility that the Grand Justices would seriously take the appointer's interests into consideration.

We tested our attitudinal hypothesis by making use of a new dataset that we constructed. The dataset includes ninety-seven decisions ("interpretations") issued by the Taiwanese constitutional court in the period between 1988 and 2008. We chose July 15, 1987, the date of the lifting of martial law in Taiwan, as the initial period because it corresponds to the start of the transition from the traditional authoritarian period to an emerging democracy. These interpretations are cases where the petitioners can be easily identified with a certain political interest (in particular, affiliated with the KMT and its allies or with the opposition). However, unlike the American model, the Taiwanese constitutional court does not entertain concrete review, but rather abstract review when it delivers a constitutional interpretation. Therefore, all the cases we have selected not only are abstract in nature but can be easily associated with political interests, as explained in more detail in the following Part. If the attitudinal model has strong support in Taiwan, these cases should be the ones to present significant evidence.

In order to test our hypotheses, we considered two different explained variables: 1) the decision whether or not to vote for constitutionality, and 2) the existence of dissenting opinions. Under our hypothesis, dissent should

19 The Presidents of Taiwan have been Chiang Kai-shek (1950-1975, KMT), Yen Chia-kan (19751978, KMT), Chiang Ching-kuo (1978-1988, KMT), Lee Teng-hui (1988-2000, KMT), Chen Shui-bian (2000-2008, DPP), and Ma Ying-jeou (since 2008, KMT). 
increase as the opposition becomes more influential in the appointment of Grand Justices. The Council was initially composed of the Grand Justices appointed by the KMT Presidents, and DPP President-appointed Grand Justices came into existence at the later stages (even though the DPP never dominated the political body confirming presidential nominations). Hence, if there is party alignment, we should observe more dissent at the later stages. As to the decision whether or not to vote for constitutionality, it should depend on the petitioner. When the petitioner is KMT-related, we expected that KMT President-appointed Grand Justices would vote for unconstitutionality (thus favoring the interests of the petitioner).

Our research shows that, although political variables do play a role in explaining the decisions made by the Council, this role is quite limited and certainly does not show notable party alignment (we test in the particular party alignment with the traditional ruling party, KMT). ${ }^{20}$ Overall, the Taiwanese constitutional court seems to be fairly insulated from main party interests. Our empirical research did not find any strong systematic interference of ideology or other political variables.

In addition, our results point to other explanations for the Council's behavior, such as a judicial concern with advancing the reputation of the court. Moreover, since dissent has become much more likely as the KMT loses its political influence and as the likelihood of the opposition gaining the presidency increases, i.e. during the political transition, we show that the alignment of interests between the Council and political parties weakened in the transition (mid-1990s to early 2000s) but was stronger before the transition period.

Our paper makes three main contributions to the growing comparative empirical studies on constitutional courts. First, it tests the attitudinal model outside the courts of the United States. Second, it provides evidence about pre- and post-transitional judicial behavior. Third, it discusses conditions under which judges in a particular court restrain their ideological biases and pursue other (more collective) interests.

In Part II of this paper, we briefly discuss the case of Taiwan and the current empirical debates. In Part III, we present our empirical results. The results are discussed further in Part IV. Part V concludes the paper.

20 Notice that we do not assign Justices to the KMT or the opposition (DPP), but rather control for which President appointed each Justice. Hence, we can distinguish between Justices appointed before the beginning of the transition (i.e., 1985 and before) and the ones appointed after democracy was introduced (i.e., 1994, 1999, 2003 and 2007). 


\section{THE CASE OF TAIWAN}

Taiwan underwent nearly one hundred years of colonial and authoritarian rule before transforming into an emerging democracy in the 1990s. ${ }^{21}$ More specifically, Taiwan was ceded by Imperial China (the Ching Dynasty) to Japan in 1895 as a result of the First Sino-Japanese War, and became a Japanese colony for fifty years until Japan was defeated in World War II in 1945. ${ }^{22}$ At the end of World War II, the troops of Chiang Kai-shek, President of the Republic of China and Director-General of the KMT as well as the Supreme Allied Commander in Asia at that time, took control of Taiwan on behalf of the Allied Forces in 1945. Followed by Chiang's defeat in the Chinese Civil War, the KMT-led government of the Republic of China declared martial law in Taiwan in May 1949, and then in the same year retreated from the Chinese mainland to Taiwan. The KMT continuously ruled Taiwan, Penghu, and several outlying Fujianese islands for fifty-five years $^{23}$ until the DPP won the presidential election in $2000 .^{24}$ The KMT imposed authoritarian rule on the Taiwanese people from 1949 until martial law was lifted in $1987 .^{25}$ This crucial political reform opened up a new era of liberalization and democratization for Taiwan. ${ }^{26}$ Later, opposition parties

21 See Tay-sheng Wang, The Legal Development of Taiwan in the 20th Century: Toward a Liberal and Democratic Country, 11 PAC. RIM L. \& POL'Y J. 531, 531-39 (2002); see also X. Xiao-Planes, Of Constitutions and Constitutionalism: Trying to Build a New Political Order in China, 1908-1949, in Building Constitutionalism IN ChINa (Stephanie Balme \& Michael W. Dowdle eds., Palgrave Macmillan 2009) (discussing the XIAN FA as a political compromise and the later enactment of the Temporary Provisions during the period of Communist Rebellion). The Temporary Provisions removed constitutional constraints imposed on the President and effectively allowed for a one-party state with no independent constitutional structures.

22 See Republic of China Yearbook 2009 /hereinafter "2009 Yearbook"], GoverNMENT INFORMATION OFFICE, http://www.gio.gov.tw/taiwan-website/5-gp/yearbook/ch03.html\#HistoryofTaiwan (last visited Sept. 14, 2010).

23 See Cheng-jung Lin, The San Francisco Peace Treaty and the Lack of Conclusions on Taiwan's International Status, TAIWAN NEWS, Sept. 10, 2001, available at http://www.twhistory.org.tw/20010910.htm (last visited Nov. 16, 2010); see also Nien-tsu (Nigel) Li. Nishuixingzhou de Xianzheng-Taiwan Jieyan Ershi Nian Huigu Xianfa Laishilu [The Constitution: March Fonward or Be Swept Away-The Post-Martial-Law Path 20 Years OnJ, 23 SI YU YAN: ReNwEN YU SHEHUIKEXUE ZAZHI [ThOUGHT AND WORD: J. HuMAN. \& SOC. SCI.] 1, 3 (2008).

24 See 2009 Yearbook, supra note 22. The DPP candidate, Chen Shui-bian, was elected in 2000 and reelected in 2004. Id. However, the KMT returned to power after its candidate, Ma Ying-jeou, won the presidential election of 2008 . Id.

25 See Wang, supra note 21, at 537-38. Parenthetically, Chiang Ching-Kuo, Chiang Kai-shek's son, was the President at the time.

26 Id. at 538; see also Sean Cooney, Why Taiwan Is Not Hong Kong: A Review of the PRC's "One Country Two Systems" Model for Reunification with Taiwan, 6 PAC. RIM L. \& POL'Y J. 497, 518 (1997); $\mathrm{Li}$, supra note 23 , at 2-3. 
were legalized in $1989,{ }^{27}$ and many restrictions on public discourse were eliminated. Beginning in 1991, various general elections have been held regularly. ${ }^{28}$ Taiwan has been a liberal democratic state ever since. ${ }^{29}$

The complex political transition (from colonial rule to authoritarian reign to democracy) has inevitably affected Taiwan's laws and its legal system. Take the current Constitution of Taiwan (which is also the Constitution of the Republic of China), ${ }^{30}$ for example. As originally drafted, the central government, according to Sun Yat-sen's political doctrines, ${ }^{31}$ is separated into five branches ("Yuan")-the Executive, Legislative, Judicial, Examination, and Control Yuans, ${ }^{32}$ with the President ${ }^{33}$ and the National Assembly ${ }^{34}$ outside the five-power scheme. Among them, the Executive, Legislative, and Judicial Yuans correspond to the conventional Montesquieuan framework. ${ }^{35}$ As to the Examination and Control Yuans, the former takes charge of entry into the civil service, and the latter is responsible for audit as well as impeachment of public officials. ${ }^{36}$ Meanwhile, the government is divided into central, provincial or municipal, and district levels. ${ }^{37}$

In addition to a complicated political structure, the legitimacy of the 1947 ROC Constitution was also called into question-at least during the

27 However, the DPP was already founded in 1986. See Tom Ginsburg, Confucian Constitutionalism? The Emergence of Constitutional Review in Korea and Taiwan, 27 LAW \& Soc. INQUIRY 763, 770 (2002) [hereinafter "Ginsburg, Confucian Constitutionalism"]

${ }_{28}$ For example, the first election for all Representatives of the National Assembly was held in 1991; the first election for all Legislators was held in 1992; and the first direct elections for President and Vice President occurred in 1996, where the KMT candidates Lee Teng-hui and Lien Chan were elected. See 2009 Yearbook, supra note 22.

29 See Wang, supra note 21 , at 539 ; see also Cooney, supra note 26 , at 518.

${ }^{30}$ The Constitution was enacted in 1946 and went into effect in 1947 in China. See GinsBurg, JUdiCIAL REVIEW, supra note 9, at 111 ; MINGUO XIANFA (1947).

31 See Denny Roy, Tarwan: A Polmtical History 84 (Comell Univ. Press 2003).

32 MINGUO XIANFA arts. 53-106.

33 The President is the head of the state and serves a six-year term with a two-term limit. MinGuo XIANFA arts. 35, 47. The President's promulgation of laws and orders requires the countersignature of the head of the Executive Yuan (the Premier). MINGUO XIANFA art. 37. Meanwhile, his or her appointment to the Premier requires the consent of the Legislative Yuan. Minguo XIANFA art. 55(1); see also Wang, supra note 21 , at 541 .

${ }^{34}$ The National Assembly is a popularly elected body that is empowered to elect or recall the president or vice president and to amend the Constitution. MiNGUO XIANFA art. 27; see also Wang, supra note 21 , at 541 .

35. These three branches represent the state's highest administrative, legislative, and judicial organs respectively. MINGUO XIANFA arts. 53, 62, 77; see also Ginsburg, Confucian Constitutionalism, supra note 27 , at 768 n. 8. 768.

36 Minguo XIANFA arts. 83, 90; see also Ginsburg, Confucian Constitutionalism, supra note 27, at

37 MINGUO XIANFA arts. 107-11, 112-20, 121-28. Because the Constitution establishes an extremely complex political structure, some have argued that the structure is more suitable for governing a huge country, such as China, than a small island such as Taiwan. See Cooney, supra note 26, at 514. 
authoritarian regime. First, the Constitution was imposed from outside without the Taiwanese people's consent or approval. Second, the government was dominated by the "Mainlanders" (approximately 13\% of the population $)^{38}$ despite the fact that the "native Taiwanese" were the overwhelming majority (around $87 \%$ of the population). ${ }^{39}$

Over and above these controversies, however, the 1947 ROC Constitution has never been completely enforced in Taiwan for several reasons. First, the National Assembly enacted the "Temporary Provisions Effective during the Period of Communist Rebellion" ("Temporary Provisions") in China in 1948. ${ }^{40}$ These Temporary Provisions suspended many provisions of the Constitution, and strengthened the President's powers $^{41}$ until their abolishment in $1991 .^{42}$ Second, the Constitution itself has been amended seven times since $1991 .^{43}$ Although these amendments (known collectively as the "Additional Articles") preserve the original text of the Constitution, they have reshaped the government structure along with political practice significantly. ${ }^{44}$

A good example is the central government. Under the 1994 and 1997 Additional Articles, the President is directly elected by the Taiwanese citizens, and serves a four-year term with a two-term limit. The President's promulgation of the personnel orders does not require the Premier's countersignature any more, and the President's appointment of the Premier also no longer requires the consent of the Legislative Yuan. Moreover, the

\footnotetext{
38 "Mainlanders" (Waishengren, literally "people from other provinces") refers to people who were born in China and emigrated from the Chinese mainland to Taiwan after 1945. See Wang, supra note 21, at 535, 537; see also GiNSBURG, JUDICIAL REVIEW, supra note 7, at 108.

39 "Native Taiwanese" (Benshengren, literally "people of this province") refers to the people who inhabited Taiwan before 1945, and their descendants. See Wang, supra note 21, at 535.

40 Dongyuan Kanluan Shiqi Linshi Tiaokuan [the Temporary Provisions Effective During the Period of Communist Rebellion] [hereinafter "Temporary Provisions"], available at http://en.wikisource.org/wiki/Temporary_Provisions_Effective_During_the_Period_of_Communist_Rebell ion (last visited Sept. 15, 2010).

41 For example, the Temporary Provisions facilitated the President's ability to issue the emergency orders, empowered the President to create extra-constitutional agencies, and suspended the two-term limit on the presidency. See Temporary Provisions, supra note 40, at arts. 1, 3, 4; see also Wang, supra note 21; Cooney, supra note 26, at 515; GINSBURG, JUDICIAL REVIEW, supra note 7, at 113-15.

${ }^{42}$ See sources cited supra note 38. Parenthetically, Lee Teng-hui, Chiang Ching-kuo's successor, was President at the time.

43 The Constitution was revised in 1991, 1992, 1994, 1997, 1999, 2000, and 2005. However, the Council of Grand Justices declared the 1999 Additional Articles unconstitutional and void because the Amendments permitted Representatives of the National Assembly to extend their own terms for almost three years. See Zhonghuaminguo Xianfa Zengxiutiaowen [The Additional Articles of the Constitution of the Republic of China], available at http://www.gio.gov.tw/info/news/additional.htm (last visited Apr. 8, 2009) [hereinafter "XIAN FA, Additional Articles"]; see also Interpretation No. 499 (March 24, 2000), Judicial Yuan Interpretations, supra note 14.

${ }^{44}$ See Cooney, supra note 26, at 520; see also Wang, supra note 21, at 542.
} 
President has the power to dissolve the Legislative Yuan when it passes a noconfidence vote against the Premier. ${ }^{45}$ This shows that Taiwan has adopted a semi-presidential system since $1997 .^{46}$ However, unlike other semipresidential countries, Taiwan has neither a constitutional mechanism nor a provision requiring the President to take into account the parliamentary election results in choosing the prime minister, ${ }^{47}$ nor a political culture of a strong legislature, such as the French tradition, ${ }^{48}$ urging the President to accept "cohabitation." As a result, Taiwan experienced a chronic political deadlock between the executive and the legislature when DPP President Chen Shui-bian refused to cohabitate with the opposition coalition (referred to as the "Pan-Blue" Alliance ${ }^{50}$ ), which dominated the Legislative Yuan over his terms (2000-2008). ${ }^{51}$

According to the 1992 and 2000 Additional Articles, the status of the Control Yuan has also been considerably altered because it is no longer a popularly elected body, and now its members, as well as the Grand Justices of the Judicial Yuan and the Members of the Examination Yuan, are all appointed by the President with the consent of the Legislative Yuan. ${ }^{52}$ Even more dramatically, the 2005 Additional Articles abolished the National Assembly, ${ }^{53}$ and set a very high threshold for constitutional amendments. ${ }^{54}$ Since then the Constitution has been extremely difficult to change.

As to the transformation of the judicial branch, under the Constitution, the Judicial Yuan, as the highest judicial organ, has the powers of: 1)

45 See XIAN FA, Additional Articles (1994), XIAN FA, Additional Articles (1997), supra note 43; see also Zhonghuaminguo Xianfa Zengxiutiaowen Lifayange [Legislative History of the Additional Articles of the Constitution of the Republic of http:/lis.ly.gov.tw/lgcgi/lglaw?@50:1804289383:f:NO\%3DE04105*\%20OR\%20NO\%3DB04105\$\$1 1\$\$\$ PD\%2BNO (last visited Nov. 16, 2010); see also XIAN FA, Additional Articles, supra note 43, at arts. 2(1), 2(2), 2(6), 3(1), 3(2).

46 For a detailed discussion, see Thomas Weishing Huang, The President Refuses to Cohabit: Semipresidentialism in Taiwan, 15 PAC. RIM L. \& POL'Y J. 375, 375-402 (2006) [hereinafter Huang, The President Refuses].

47 Id. at 387 .

48 The tradition of a strong legislature existed at least between the Third and Fourth Republics. See Huang, The President Refuses, supra note 46, at 386.

49 Id. at $385,387$.

so This alliance was formed by the KMT and the People First Party ("PFP"). See Background Note: Taiwan, U.S. DEP'T OF STATE, BuREAU OF EAST ASIA AND PAC. AFFAIRS (updated Apr. 30, 2010), http://www.state.gov/r/pa/ei/bgn/35855.htm (last visited Sept. 15, 2010).

51 See Huang, The President Refuses, supra note 46, at 386.

52 See XIAN FA, Additional Articles, supra note 43, at arts. 5(1), 6(2), 7(1), 7(2).

53 Id. at art. 1

54 Id. at art. 12 ("Amendment of the Constitution shall be ... passed by at least three-fourths of the [legislators] present at a meeting attended by at least three-fourths of the total members of the Legislative Yuan, and sanctioned by electors ... a at a referendum ... wherein the number of valid votes in favor exceeds one-half of the total number of electors...."). 
adjudicating civil, criminal, and administrative cases, and cases concerning disciplinary measures against public officials, ${ }^{55}$ and 2 ) interpreting the Constitution as well as unifying the interpretations of laws and ordinances. ${ }^{56}$ However, the 1997 and 2005 Additional Articles have expanded the power of the Judicial Yuan ${ }^{57}$ by empowering the Grand Justices to adjudicate cases relating to the impeachment of the President or the Vice President, and concerning the dissolution of unconstitutional political parties. ${ }^{58}$ In order to safeguard judicial independence, the Additional Articles have also prohibited the Executive Yuan from eliminating or reducing the annual budget proposal of the Judicial Yuan since $1997 .^{59}$

The Council of Grand Justices can play a significant role in the following scenarios: 1) dealing with the "most contentious moral and political issues," as do its counterparts in other democracies, ${ }^{60}$ 2) being an arbiter when a political deadlock occurs between the executive and the legislature under the present semi-presidential system, ${ }^{61} 3$ ) interpreting the Constitution authoritatively, especially when it becomes very difficult to amend, and 4) deciding some of the most politically controversial cases (e.g., impeaching the President or dissolving an "unconstitutional" political party). Unsurprisingly, it has become a more coveted object for various political, economic, and judicial actors than ever. ${ }^{62}$ Even so, one must not neglect that in the authoritarian era, the Council operated as an instrument of the KMT regime, rather than a guardian of the Constitution. ${ }^{63}$ The most

55 MLNGUO XIANFA art. 77. However, in practice, those cases are adjudicated by the ordinary court system, the Administrative Courts, and the Commission on the Disciplinary Sanction of Functionaries, which are outside the Judicial Yuan but under its supervision. Because these practices have made the Judicial Yuan "the highest judicial administrative organ," rather than the highest judicial (adjudicative) organ, the related laws were declared unconstitutional in 2001. See Interpretation No. 530 (Oct. 5 2001), Judicial Yuan Interpretations, supra note 14.

56 Minguo XIANFA art. 78. The power of judicial review lies with the Council of Grand Justices, a component of the Judicial Yuan. See Wang, supra note 21, at 545; see also Ginsburg, Confucian Constitutionalism, supra note 27 , at 768 .

57 See Huang, Judicial Activism, supra note 17, at 4.

58 See XIAN FA, Additional Articles, supra note 43, at art. 5(4).

59 See XIAN FA, Additional Articles, supra note 43, at art. 5(6) (1997).

60 See Ran Hirschl, Book Review: Judicial Review in New Democracies: Constitutional Courts in Asian Cases by Tom Ginsburg, 13 L. \& POL'Y BOOK REV. 1 (2003), available at http:/www.bsos.umd.edu/gvpt//pbr/subpages/reviews/Ginsburg1203.htm (last visited Nov. 16, 2010) [hereinafter Hirschl, Book Review].

61 A good example is Interpretation No. 632, which was filed by the DPP legislators because the Pan-Blue-dominated Legislative Yuan had refused to exercise its consent power over President Chen's nominees of the Members of the Control Yuan for more than two and a half years. The Council finally ruled the action of the legislature unconstitutional. Interpretation No. 632 (Oct. 15 2007), Judicial Yuan Interpretations, supra note 14.

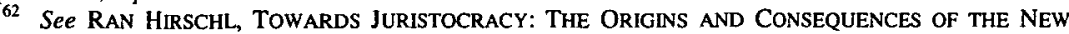
CONSTITUTIONALISM 11-12 (Harvard Univ. Press 2004) [hereinafter HIRSCHL, ToWARDS JURISTOCRACY].

${ }_{63}$ See Wang, supra note 21, at 545; see also GINSBURG, JUDICLAL REVIEW, supra note 9, at 130-34. 
infamous example was Interpretation No. 31 of 1954, in which the Council allowed the Members of the Legislative Yuan, Control Yuan and National Assembly elected in China in 1948 to remain in power for more than forty years. ${ }^{64}$

Unlike the judicial appointment mechanism in Germany, Italy, Portugal, or Spain, ${ }^{65}$ a de facto quota system does not exist in Taiwan. That is to say, there is no mechanism for Taiwan's political parties to select the Justices according to their seats in the Legislative Yuan or their relative importance in the Taiwanese society. Therefore, it is relatively difficult to identify a particular Justice with a political party, at least compared with the German, Italian, Portuguese and Spanish cases, ${ }^{66}$ Moreover, career judges in Taiwan are forbidden to have party affiliations, ${ }^{67}$ so it is even more difficult to recognize a Justice's party preferences if he or she used to be a career judge. However, even without a party quota system, practically speaking, the president still needs to take the general election results, along with his or her own approval rate, the Justice nominee's reputation, etc., into account. ${ }^{68}$

Since the lifting of martial law in 1987, fifty Grand Justices have served on the bench. Except the five Justices newly appointed by President Ma Ying-jeou, ${ }^{69}$ our research covers the other forty-five Justices ${ }^{70}$ who were respectively appointed by President Chiang Ching-Kuo in 1985 (i.e. the fifth term), by President Lee Teng-hui in 1994, 1999 (i.e. the sixth term), and by

64 See Wang, supra note 21, at 543-44; see also Interpretation No. 31 (Jan. 29 1954), Judicial Yuan Interpretations, supra note 14. However, the Council eventually overturned Interpretation No. 31 . See Interpretation No. 261 (June 21, 1990), Judicial Yuan Interpretations, supra note 14.

65 See Nuno Garoupa, The Politicization of the Kelsenian Constitutional Courts: Empirical Evidence, in EMPIRICAL JUDICIAL STUDIES (Kuo-chang Huang ed., 2008).

66 See id.

67 MEGUO XIANFA art. 80; see also OAJY, supra note 14, at art. 5.

68 Otherwise, his or her nominees may be voted down when there is an opposition-controlled Legislative Yuan (as there was under DPP President Chen). A good example took place in 2007 when, among the eight Justice candidates nominated by President Chen, only four were approved by the PanBlue-dominated Legislative Yuan. See Shih Hsiu-chuan, Four Grand Justices Approved, Four Rejected, TAIPEI TIMES, Sept. 28, 2007, http://www.taipeitimes.com/News/front/archives/2007/09/28/2003380727 (last visited Nov. 16, 2010).

${ }_{69}$ See Shih Hsiu-chuan, Legislators Approve Ma's Five Nominees Despite DPP Boycott, TAIPEI TIMES, Oct. 4, 2008, http://www.taipeitimes.com/News/taiwan/archives/2008/10/04/2003424994/wikj (last visited Nov. 16, 2010).

70 One must note that we have only forty-four of them in our dataset. The reason is that Fan ShinShiang, a former Supreme Court female judge and also a Chiang's Mainlander appointee, did not attend the court meetings after July 1987 due to suffering from liver cancer, and eventually dying in November 1987 Therefore, we do not include her in the dataset. See Council for Cultural Affairs of the ROC, Taiwan Lishi Cidian [Dictionary of the Taiwan History] http:/nrch.cca.gov.tw/ccahome/website/site20/contents/009/cca220003-li-wpkbhisdict002006-0612-u.xml (last visited Sept. 15, 2010) (in Chinese). 
President Chen Shui-bian in 2003 as well as in 2007.1 Among them, twenty-three Justices used to be Supreme Court judges of the ordinary court system (OAJY art. 4.1.1); nineteen used to be law professors (OAJY art. 4.1.3); two were senior prosecutors; and only one was a legislator (OAJY art. 4.1.2). ${ }^{72}$ In addition, $81 \%$ of Chiang's appointees were Mainlanders; on the contrary, $79 \%$ and $74 \%$ of Lee and Chen's appointees respectively were native Taiwanese. Obviously, the China-born President Chiang tended to select Mainlanders as Justices, despite the fact that they only represented 13$15 \%$ of the population. Contrarily, native-born Presidents (i.e. Lee and Chen) tended to appoint more native Taiwanese to the bench, even though it still did not reflect the population ratio.

As mentioned above, the Grand Justices, as a whole, now have the following powers: 1) to interpret the Constitution, 2) to unify the interpretations of laws and ordinances, 3 ) to adjudicate cases relating to the impeachment of the president or the vice president, and 4) to declare the dissolution of unconstitutional political parties. ${ }^{73}$ According to the Constitutional Interpretation Procedure Act of 1993 ("CIPA"), different procedures apply in the above different powers. ${ }^{74}$ In short, the Council conducts abstract review in the first two categories of jurisdiction, and forms a Constitutional Court to hear the last two types of "cases or controversies" (i.e. to exercise concrete review) ${ }^{75}$ Considering, first, that there is no case of the impeachment of a president or vice president or the dissolution of an unconstitutional party so far, and second, that interpreting the Constitution is the core of constitutional review, our research thus concentrates on the Justices' interpretations ruled under Article 5 of the CIPA ${ }^{76}$ - especially all

7 See Justices of the Constitutional Court-Judicial Yuan, Former Justices, http://www.judicial.gov.tw/constitutionalcourt/en/p01_04.asp (last visited Apr. 8, 2009); see also, Justices of the Constitutional Court-Judicial Yuan, Justices, http://www.judicial.gov.tw/constitutionalcourt/en/p01_03.asp (last visited Apr. 8, 2009).

72 OAJY, supra note 14, at art. 4. "To be eligible for appointment as a Justice of the Constitutional Court, a candidate must: (1) have served as a Justice of the Supreme Court for more than ten years . . . ; or (2) have served as a Member of the Legislative Yuan for more than nine years . . . ; or (3) have been a [law] professor ... for more than ten years . . . ; or (4) have served as a Justice of the International Court, or have had authoritative works published in the fields of public or comparative law; or (5) be a person highly reputed in the field of legal research and have political experience. The number of Justices qualifying under any single qualification listed above shall not exceed one third of the total number of Justices." Id.

73 See MinguO XIANFA arts. 78-79; see also XIAN FA, Additional Aricles, supra note 43, at art. 5.

74 See Constitutional Interpretation Procedure Act of 1993 ("CIPA") http://www.judicial.gov.tw/constitutionalcourt/en/p07_2.asp?lawno=73 (last visited Apr. 8, 2009) [hereinafter "CIPA"].

75 See JACKSON \& TUSHNET, supra note 14 , at 468.

76 CIPA, supra note 74, at ar. 5.1. "A petition for an interpretation of the Constitution may be filed under one of the following circumstances: (1) Where a central or local government agency is uncertain regarding the application of the Constitution in exercising its powers, or, where the agency, while 
the cases filed under Articles 5.1.1 and 5.1.3 (in these cases the petitioners are either the central government, local governments or at least one-third of legislators), as well as a few cases which are also party politics-related, filed under Articles 5.1.2 and 5.2 (in these cases the petitioners are individuals, legal persons, political parties, or judges of the other courts $\left.{ }^{77}\right){ }^{78}$

Although an individual or a judge of the other courts may file a petition for a constitutional interpretation under Articles 5.1.2 or 5.2 of the CIPA, one must note that it is not concrete review under the "American" model because the Council cannot directly declare a court's final decision unconstitutional as the Supreme Court of the United States or Japan can. ${ }^{79}$ Instead, the Council can only interpret the constitutionality of the laws, regulations, or legal precedents on which the court's decision is based. ${ }^{80}$ Furthermore, although our research mainly focuses on those cases filed under Articles 5.1.1 and 5.1.3 of the CIPA on account of their political nature and importance, in fact, the cases filed by individuals (i.e. the cases of Article 5.1.2) still form a vast part of the Council's docket. ${ }^{81}$

exercising its powers, is in dispute with another agency regarding the application of the Constitution, or where the agency is uncertain of the constitutionality of a particular law or order when applying it; (2) Where an individual, a legal person, or a political party, having exhausted all judicial remedies provided by law, alleges that her/his/its constitutional rights have been infringed upon and thereby questions the constitutionality of the law or order applied by the court of last resort in its final decision; (3) Where the members of the Legislative Yuan, in exercising their powers, are uncertain regarding the application of the Constitution or regarding the constitutionality of a particular law when applying the same, and at least onethird of the members of the Legislative Yuan have filed a petition." Id. Besides, since Interpretation No. 371 expanded the application of art. 5.2, now when any judge of any court sincerely believes the statute or regulation at issue before the court is in conflict with the Constitution, the court may adjourn the proceedings and petition the Constitutional Court to interpret the constitutionality of the said statute or regulation. Interpretation No. 371 (Jan. 20 1995), Judicial Yuan Interpretations, supra note 14. Additionally, unlike the justices of the U.S. Supreme Court, the Grand Justices have no discretion when determining which cases they would like to hear. In other words, the Grand Justices have to deal with all of the petitions unless a petition does not meet the requirements of CIPA and, in that case, the Council should dismiss the case without issuing any interpretation.

$n$ They include the ordinary court system, the Administrative Courts, and the Commission on the Disciplinary Sanction of Functionaries. See sources cited supra note 53.

78 Out of ninety-seven decisions in our dataset, seven were filed under Article 5.1.2 and one under Article 5.2; hence, the remaining eighty-nine decisions were filed under Articles 5.1.1 and 5.1.3

In addition to this difference, there are other distinctions between the Council and the Supreme Court of the United States or Japan. For example, in Taiwan the President, the other four Yuans, or even one-third of legislators have the right to challenge, on an "abstract" basis, the constitutionality of laws enacted by the Legislative Yuan. In this case, many of the "cases or controversies" doctrines that form an important part of the U.S. constitutional jurisprudence cannot be naturally applied.

80 See CIPA, supra note 74, at art. 4; see also Interpretations Nos. 154, 271, 374, 569, 582, Judicial Yuan Interpretations, supra note 14.

81 For example, in the fifth and sixth terms, $97 \%$ and $92 \%$ of petitions respectively were filed by individuals. In addition, $72 \%$ and $75 \%$ of interpretations, based on the cases filed by individuals, were ruled on. See Statistics, http://www.judicial.gov.tw/constitutionalcour/uploadfile/E100/第一屆至第六屆大法官就機關聲請者與 人民㹂請者整請解釋之比例作一統計.htm; 
An absolute majority of votes is required to declare a constitutional interpretation. More specifically, prior to 1993, an interpretation could only be adopted by the votes of a three-fourths majority of those attending Justices with a quorum consisting of three-fourths of all Justices. ${ }^{82}$ In 1993, the CIPA was amended; an interpretation can now be adopted by the votes of a two-thirds majority of those attending Justices with a quorum consisting of two-thirds of all Justices. ${ }^{83}$ Before 1993, those Justices who had separate opinions could only issue so-called "dissenting opinions," even though they agreed with the ruling and only had opinions about the reasoning. ${ }^{84}$ However, since 1993, the Justices who have separate opinions can issue either concurring or dissenting opinions, and those opinions are proclaimed along with the interpretations of the Council. ${ }^{85}$

Under the Constitution, the Council has the power to declare laws and ordinances unconstitutional and void. ${ }^{86}$ However, similarly to other "Kelsenian" constitutional courts (e.g. the German "Bundersverfassungsgericht" and the Austrian "Verfassungsgerichtshof"), the Council does not always explicitly declare a law or a governmental action unconstitutional or invalid even when the law or the action is not in conformity with the Constitution. ${ }^{87}$ For example, in Interpretation No. 419 of 1996, although the Council did not proclaim that the status of the Vice President concurrently serving as Premier of the Executive Yuan was apparently unconstitutional, it still concluded that this situation was "constitutionally inappropriate." $" 88$ Another example is Interpretation No. 530 of 2001 . In this interpretation the Council struck down the related laws including the OAJY, the Organic Act of Court, and the Organic Act of the Administrative Court, but it did not declare them immediately void and

http:/www.judicial.gov.tw/constitutionalcourt/uploadfile/E100/第一届至第六屆大法官作成解釋之統計 数拨表.htm (in Chinese) (last visited Apr. 8, 2009).

82 See The Act of the Council of Grand Justices of the Judicial Yuan of 1958 art. 13(1), available at http:/www.judicial.gov.tw/constitutionalcourt/p07_2_one.asp?lawno=61\&types=all (in Chinese) (last visited Apr. 8, 2009) [hereinafter "ACGJ"].

83 See CIPA, supra note 74, at art. 14(1).

84 See ACGJ, supra note 82, at art. 17.

85 See CIPA, supra note 74, at art. 17. However, it is important to note that the Justices vote secretly. Therefore, if a Justice's vote turns out to be a minority but he or she refuses to write any separate (especially dissenting) opinion then, according to the public record, his or her vote will still be counted as a majority. In this case, one might interpret that the specific Justice changes his or her opinion afterward. Or more likely, the Justice tends not to publish his or her opinion since there are different political parties and interest groups that have lobbied the judge before the vote and the justice does not want to publicize his or her individual decision.

86 See Minguo Xianfa arts. 171, 172.

87 See Interpretation No. 419 (Dec. 31 1996), Judicial Yuan Interpretations, supra note 14

88 See id. 
instead granted the Legislative Yuan two years to revise the laws. ${ }^{89}$ These two examples have shown that the Council usually plays a cautious and selfrestricted role when encountering other branches of the government or important political actors. In return, the government(s) and political parties in Taiwan generally will respect the decisions of the court. A good example is Interpretation No. 419. Although the Council did not explicitly prohibit the Vice President from serving as the premier simultaneously, after this Interpretation was released, then-Vice President Lien Chan still resigned his post as the premier. Of course, there are a few exceptions as well. For instance, in Interpretation No. 530, the Council demanded the Legislative Yuan to amend the unconstitutional laws in two years. However, nine years have passed. The legislature has not done anything yet.

With the exception of our paper, we are not aware of empirical studies on the relationship between Grand Justices and party politics. In fact, the only relevant paper that we have found is an empirical study of the Justices' separate opinions. ${ }^{90}$ That paper has shown: 1) lowering the decision threshold had a positive relation to the appearance of dissenting opinions, 2) the appearance of dissenting opinions in "abstract interpretations" (i.e. the cases of articles 5.1.1 and 5.1.3 of the CIPA) is vastly higher than that in "concrete interpretations" (i.e. the cases of articles 5.1.2 and 5.2 of the CIPA), and the number of separate opinions in "abstract interpretations" is more than that in "concrete interpretations", 3) reappointed Justices wrote fewer separate opinions than average, and 4) Justices with backgrounds as career judges wrote more separate opinions than those with backgrounds as law professors.

However, these interesting findings do not illustrate the extent to which the Council, as a "Kelsenian" constitutional court in the emerging Taiwanese democracy, maintains judicial independence or is inevitably influenced by party politics as are its counterparts in other democracies, such as Germany, Italy, Portugal, France and Spain. ${ }^{91}$ Therefore, our research can be regarded as an initial checkpoint to examine what role the Council has played for Taiwan on its way towards a dynamic constitutional democracy. ${ }^{92}$

89 See Interpretation No. 530 (Oct. 5 2001), Judicial Yuan Interpretations, supra note 14.,

90 Dennis Te-chung Tang, Dafaguanjieshi Butongyijian de Shizhengyanjiu [An Empirical Study of Separate Opinions in the Council of Grand Justices of Taiwan], in QUANLIFENLI XINLUN: JUANER. WEIXIANSHENCHA YU DONGTAIPINGHENG [SEPARATION OF POWERS REVISITED: VOLUME II. CONSTITUTIONAL REVIEW AND Dynamic BalanCE] 427-89 (Yuanzhao Press 2005).

91 See Garoupa, supra note 65.

92 For another example of this literature, see Wen-Cheng Chang, East Asian Foundations for Constitutionalism: Three Models Reconstructed, 3 NAT'L TAIWAN U. L. REV. 111 (2009). 


\section{THE DATA AND RESUlts}

We have coded ninety-seven decisions of the Taiwanese constitutional court from 1988 to 2008 . We have included all cases that are political in nature, as explained in more detail in the previous Part. These decisions have obvious political content and thus do not require second-guessing concerning the political interests involved. They include all cases of abstract interpretations (filed under articles 5.1.1 and 5.1.3 of the CIPA) and some cases of concrete interpretations (filed under articles 5.1.2 and 5.2 of the CIPA) in that period. ${ }^{93}$

The coding of some cases has to address the peculiarities of the Taiwanese system of concurring and dissenting opinions (also known as separate opinions), as explained before. At the same time, we have to make sure that the different political interests are correctly identified. In the Appendix, we present details of the coding of the controversial cases (i.e. those that require a more comprehensive explanation concerning the identification of "concurring" and "dissenting" opinions). ${ }^{94}$

Our sample of Grand Justices includes forty-four individuals (since the forty-fifth has not cast her vote in the cases we have coded).$^{95}$ The general descriptive statistics concerning gender, first-time appointment/reappointment, career backgrounds, and origins (i.e. Mainlander or Native Taiwanese) are summarized in Table One below:

TABLE 1

CHARACTERISTICS OF TAIWANESE CONSTITUTIONAL COURT JUDGES, 1985-2007

\begin{tabular}{lccc}
\hline & $\begin{array}{c}\text { Appointed by } \\
\text { Chiang Ching-kuo } \\
(1985)\end{array}$ & $\begin{array}{c}\text { Appointed by } \\
\text { Lee Teng-hui } \\
(1994 ; 1999)\end{array}$ & $\begin{array}{c}\text { Appointed by } \\
\text { Chen Shui-bian } \\
(2003 ; 2007)\end{array}$ \\
\hline Judges Attribute & 15 & 19 & 19 \\
\hline Mainlander & 12 & 4 & 3 \\
\hline $\begin{array}{l}\text { Second generation } \\
\text { Mainlander }\end{array}$ & 0 & 0 & 2 \\
\hline Native Taiwanese & 3 & 15 & 14 \\
\hline
\end{tabular}

93 See supra text accompanying note 78.

94 See supra text accompanying note 85 . Our sample probably underestimates actual dissent so, in this sense, we studied only reported dissent.

${ }_{95}$ See supra text accompanying note 70. 


\begin{tabular}{lccc}
\hline Career Magistrate & 9 & 7 & 8 \\
\hline Law Professor & 5 & 11 & 9 \\
\hline $\begin{array}{l}\text { First Time } \\
\text { Appointment }\end{array}$ & 12 & 16 & 13 \\
\hline $\begin{array}{l}\text { Reappointment by a } \\
\text { Different President }\end{array}$ & $3\left(^{*}\right)$ & 3 & 6 \\
\hline Female & 0 & 1 & 3 \\
\hline Male & 15 & 18 & 16
\end{tabular}

Source: Taiwanese Constitutional Court, 1985-2007

Note: Some judges are counted more than once because they were appointed and reappointed by different Presidents.

(*) Two were originally appointed by Yen Chia-kan (1976) and one by Chiang Kai-shek (1972).

We have constructed two dependent variables:

1) Dissent in the court: For each decision of the Council, this variable takes the value one if there is dissent (in the sense of a separate opinion that disagrees with the decision made by the majority of the court), and zero if there is no dissent (all Grand Justices agree with the decision made by the court, even if there are separate or concurring opinions), and

2) Voting for constitutionality: For each individual vote by a Grand Justice, this variable takes the value one if it upheld constitutionality (hence, a decision against the petitioner), and zero otherwise (hence, a decision favorable to the petitioner).

\section{A. Dissent}

We start by a descriptive analysis of dissent rates (number of decisions with dissent over total number of decisions) in the Council per term. Almost two-thirds of the decisions in our sample are voted unanimously (even if they include separate opinions that do not disagree with the decision of the Council) while slightly more than a third have dissenting votes (that is, separate opinions that disagree with the outcome derived from the majority opinion). In the early period of the transition to democracy (1988-1994), the dissent rate is less than $30 \%$, but it rises up to $50 \%$ in the following decade (1995-2003). And again the dissent rate descends to approximately $20 \%$ during 2004 to 2008 as democracy has taken root. See Table Two below: 
TABLE 2

DISSENT IN THE COURT BY YEARS

\begin{tabular}{lccc}
\hline & $\begin{array}{c}\text { Number of } \\
\text { Decisions Without } \\
\text { Dissent }\end{array}$ & $\begin{array}{c}\text { Number of } \\
\text { Decisions With } \\
\text { Dissent }\end{array}$ & $\begin{array}{c}\text { Percentage of } \\
\text { Dissent }\end{array}$ \\
\hline $1988-1994$ & 22 & 9 & $29.0 \%$ \\
\hline $1995-2003$ & 19 & 19 & $50.0 \%$ \\
\hline $2004-2008$ & 22 & 6 & $21.4 \%$ \\
\hline Total & 63 & 34 & $35.1 \%$ \\
\hline $\begin{array}{l}\text { Source: Taiwanese Constitutional Court, 1985-2007; own calculations. } \\
\text { Testing for statistical significance: Pearson Chi-Square Statistics }=6.51 \text { (p-value=0.039); degrees of } \\
\text { freedom=2. }\end{array}$
\end{tabular}

In our view, these descriptive results do not support our attitudinal hypothesis. Dissent rates increase while the Council is fully dominated by Justices appointed by KMT Presidents. Besides, dissent rates go down precisely when the Council is dominated by the Justices appointed by DPP President Chen. These descriptive results seem to be inconsistent with the attitudinal model.

The regression analysis largely confirms our analysis. The explained variable is the existence of dissent in the court with respect to a decision. The explanatory variables include:

1) Petitioner is a KMT supporter..$^{96}$ The expected sign of the coefficient is negative if the political allegiance hypothesis holds; that is, due to the overwhelming influence of the KMT on the appointment of Grand Justices in the period, we should expect less dissent when the petitioner is a KMT supporter.

2) Percentage of the DPP in the Legislative Yuan. This variable controls for the likelihood that democracy is consolidated. The expected sign of the coefficient is positive if the attitudinal hypothesis is true; that is, as the percentage of the DPP in the Legislative Yuan increases, democracy is more consolidated and the opposition becomes more politically influential, hence, we expect more dissent. ${ }^{97}$

96 This variable takes the value one if the petitioner(s) is mainly the supporter of KMT and takes the value zero otherwise. For each case, we have identified the petitioners and have coded supporters of KMT when there is a direct link to the party. Inevitably there are some subjective judgments in a small handful of cases, but we are confident that our coding captures the intended effect.

97 These percentages range from $28 \%$ in the late 1980 s to $32 \%$ in 1999 . These percentages then jump to approximately $45 \%$ for most of $2000-2007$, and back to $24 \%$ in 2008 . Note that these percentages are 
3) Timing control variables, including President Lee in power (1988-2000) and time dummies which control, for example, for the 1993 change of the CIPA concerning the decision threshold and the writing of separate opinions as well as for the 2000 amendment of the Constitution (effective in 2003) with respect to Justices' appointment and term in office.

4) Judicial control variables to capture the attributes of the Grand Justices deciding in each particular decision, including gender (number of female Justices), previous career (number of career judges and number of law professors), Mainlanders (number of Justices who are the first and second generations of Mainlanders), reappointment (number of Justices who were reappointed), and number of Justices appointed by each of the three Presidents (i.e. Chiang, Lee and Chen). ${ }^{98}$

5) Case control variables to capture potential particular characteristics of each decision, including specific disputes (mainly between central and regional governments-regional and across different branches of powerbalance of power), ${ }^{99}$ and duration of making a decision in months. ${ }^{100}$

6) Interaction terms between number of Grand Justices appointed by each of the three Presidents (i.e. Chiang, Lee and Chen) ${ }^{101}$ and whether the petitioner is a KMT supporter. These interaction variables should capture any particular bias of Grand Justices appointed by Presidents Chiang and Lee in favor of the KMT, and appointed by President Chen, on the contrary, against the KMT.

7) Economic control variables, including annual inflation rate, annual unemployment rate, and annual Gross Domestic Product ("GDP”) per capita.

\footnotetext{
always strictly less than $50 \%$, which reflects the fact that DPP and its allies have never dominated the Legislative Yuan.

${ }_{98}$ It is important to note that each class is not mutually exclusive because of reappointments and the fact that some Grand Justices were appointed by previous Presidents. See supra Table 1 .

99 This variable takes value one if it is a specific case as explained and takes a value of zero otherwise. Specific cases include all cases in relation to independence of Taiwan, balance of power among the President, National Assembly, and five branches of government, and power disputes between central and local governments.

${ }^{100}$ Given the small number of cases in our sample resulting from petitions filed under Articles 5.1 .2 and 5.2 of the CIPA, these control variables could not be included. CIPA, supra note 72, arts. 5.1.2 \& 5.2.

101 Note that there are Justices appointed by previous Presidents so these three variables are not linearly dependent. See supra text accompanying note 96.
} 
These variables capture the context under which the court has issued a decision. ${ }^{102}$

Due to the fact that some explanatory variables are correlated and due to the limited number of observations, we have used different specifications as shown in Table Three below. Usually with this type of logit regression, we should consider the signal and not place too much emphasis on the magnitude of the estimated coefficients. In other words, we do not assess quantitatively the marginal impact of each explanatory variable on the probability of dissent taking place, but rather it is assessed qualitatively. Due to the non-independence of the votes within cases (recall that each case might have more than one decision, that is, each petition might address several articles of the same law and each article is addressed by a different decision), we have estimated the different logits with cluster by case (and not by judge since we are looking at aggregate data). The econometric package used for the estimation is Stata [version 10].

TABLE 3

LOGIT REGRESSION OF DISSENT IN THE COURT $(=1$ YES,$=0$ No) WITH CluSTER BY CASE

\begin{tabular}{lcccccc}
\hline \multicolumn{1}{c}{ Coefficients } & Logit 1 & Logit 2 & Logit 3 & Logit 4 & Logit 5 & Logit 6 \\
\hline Number of J. Appointed & 0.24 & 0.31 & 0.35 & 0.39 & & $-1.18^{*}$ \\
\hline by President Chiang & $(0.17)$ & $(0.26)$ & $(0.30)$ & $(0.35)$ & & $(-2.09)$ \\
\hline $\begin{array}{l}\text { Number of J. Appointed } \\
\text { by President Lee }\end{array}$ & 0.03 & 0.14 & & & & 1.04 \\
\hline $\begin{array}{l}\text { Number of J. Appointed } \\
\text { by President Chen }\end{array}$ & $(0.05)$ & $(0.21)$ & & & & $(-1.93)$ \\
\hline $\begin{array}{l}\text { N. J. Appointed } \\
\text { by President Chiang \& }\end{array}$ & $(1.44)$ & $(1.34)$ & & & & -0.15 \\
KMT Petitioner & 0.69 & & 0.56 & & $0.0 .29)$ \\
\hline N. J. Appointed & $1.99)$ & & $(1.02)$ & $(0.79)$ & \\
by President Lee \& KMT & $(1.50)$ & & $(1.16)$ & & $(1.28)$ & \\
Petitioner & & & & & & \\
\hline $\begin{array}{l}\text { N. J. Appointed } \\
\text { by President Chen \& KMT }\end{array}$ & -5.05 & & -1.69 & & -1.58 & \\
Petitioner & $(-1.89)$ & & $(-0.96)$ & & $(-1.18)$ & \\
\hline Specific Disputes & -0.22 & -0.27 & & & \\
& $(-0.35)$ & $(-0.43)$ & & & & \\
\hline
\end{tabular}

102 Some of these control variables follow the reasoning exposed in the econometric analysis of dissent in the High Court of Australia. See Narayan \& Smyth, supra note 11. Narayan and Smyth argue that economic growth could be associated with higher or lower dissent rates. Id. At the same time, more complex economic environments should be positively related to the level of dissent. Id. Hence, we may expect unemployment and inflation to have a positive coefficient. 


\begin{tabular}{|c|c|c|c|c|c|c|}
\hline $\begin{array}{l}\text { Disputes on Regional } \\
\text { Powers }\end{array}$ & & & $\begin{array}{c}0.22 \\
(0.24) \\
\end{array}$ & $\begin{array}{c}0.29 \\
(0.31)\end{array}$ & & \\
\hline $\begin{array}{l}\text { Disputes on Balance of } \\
\text { Powers }\end{array}$ & & & $\begin{array}{c}-0.31 \\
(-0.53)\end{array}$ & $\begin{array}{c}-0.35 \\
(-0.58)\end{array}$ & & \\
\hline Number of Female & $\begin{array}{l}-5.78^{*} \\
(-2.02) \\
\end{array}$ & $\begin{array}{c}-4.79 \\
(-1.81)\end{array}$ & $\begin{array}{l}-1.08 \\
(-0.75)\end{array}$ & $\begin{array}{c}-1.12 \\
(-0.82)\end{array}$ & $\begin{array}{l}-5.64 * * \\
(-3.15) \\
\end{array}$ & $\begin{array}{l}-4.95^{*} \\
(-2.24) \\
\end{array}$ \\
\hline $\begin{array}{l}\text { Number of Career } \\
\text { Magistrates }\end{array}$ & $\begin{array}{c}-0.77 \\
(-0.84) \\
\end{array}$ & $\begin{array}{c}-0.79 \\
(-0.89) \\
\end{array}$ & $\begin{array}{c}-1.15 \\
(-1.45) \\
\end{array}$ & $\begin{array}{c}-1.01 \\
(-1.38) \\
\end{array}$ & $\begin{array}{c}-0.81 \\
(-0.84) \\
\end{array}$ & $\begin{array}{l}0.69 \\
(1.11) \\
\end{array}$ \\
\hline $\begin{array}{l}\text { Number of Law } \\
\text { Professors }\end{array}$ & $\begin{array}{c}0.47 \\
(0.48)\end{array}$ & $\begin{array}{c}0.31 \\
(0.32)\end{array}$ & $\begin{array}{c}0.40 \\
(0.88)\end{array}$ & $\begin{array}{c}0.43 \\
(0.97)\end{array}$ & $\begin{array}{c}0.82 \\
(0.91)\end{array}$ & $\begin{array}{l}1.93 \\
(1.82)\end{array}$ \\
\hline $\begin{array}{l}\text { Number of Mainlanders } \\
\text { [First \& Second Gen.] }\end{array}$ & $\begin{array}{c}-0.18 \\
(-0.13)\end{array}$ & $\begin{array}{c}-0.09 \\
(-0.09)\end{array}$ & $\begin{array}{c}-0.49 \\
(-0.37)\end{array}$ & $\begin{array}{c}-0.50 \\
(-0.40)\end{array}$ & $\begin{array}{c}0.58 \\
(0.68)\end{array}$ & \\
\hline $\begin{array}{l}\text { Number of Justices } \\
\text { Reappointed }\end{array}$ & $\begin{array}{c}-0.36 \\
(-0.42) \\
\end{array}$ & $\begin{array}{c}-0.37 \\
(-0.48) \\
\end{array}$ & $\begin{array}{c}0.54 \\
(0.59) \\
\end{array}$ & $\begin{array}{c}0.37 \\
(0.44)\end{array}$ & $\begin{array}{c}0.31 \\
(0.28) \\
\end{array}$ & \\
\hline $\begin{array}{l}\text { Duration of Case } \\
\text { in Months }\end{array}$ & $\begin{array}{c}-0.00 \\
(-0.05)\end{array}$ & $\begin{array}{c}-0.01 \\
(-0.37) \\
\end{array}$ & $\begin{array}{c}-0.01 \\
(-0.52) \\
\end{array}$ & $\begin{array}{c}-0.02 \\
(-0.66) \\
\end{array}$ & $\begin{array}{c}-0.02 \\
(-0.88) \\
\end{array}$ & \\
\hline $\begin{array}{l}\text { President Lee in Power } \\
(1988-2000)\end{array}$ & $\begin{array}{c}-3.71 \\
(-0.98) \\
\end{array}$ & $\begin{array}{l}-5.25 \\
(-1.45) \\
\end{array}$ & $\begin{array}{l}-3.68 \\
(-1.74) \\
\end{array}$ & $\begin{array}{l}-4.40^{*} \\
(-2.00) \\
\end{array}$ & & \\
\hline $\begin{array}{l}\text { Percentage of DPP in } \\
\text { Legislative Yuan }\end{array}$ & $\begin{array}{l}-0.40^{*} \\
(-2.45) \\
\end{array}$ & $\begin{array}{l}-0.44^{*} \\
(-2.28) \\
\end{array}$ & $\begin{array}{l}-0.32^{*} \\
(-2.38) \\
\end{array}$ & $\begin{array}{l}-0.35^{*} \\
(-2.27) \\
\end{array}$ & $\begin{array}{c}-0.24 \\
(-1.90) \\
\end{array}$ & $\begin{array}{l}-0.09 \\
(-1.66) \\
\end{array}$ \\
\hline $\begin{array}{l}\text { Party Filing is } \\
\text { KMT "Supporter" }\end{array}$ & $\begin{array}{l}-10.89 \\
(-0.95) \\
\end{array}$ & $\begin{array}{c}-1.06 \\
(-1.88) \\
\end{array}$ & $\begin{array}{c}-9.91 \\
(-1.05) \\
\end{array}$ & $\begin{array}{l}-1.19^{*} \\
(-2.02)\end{array}$ & $\begin{array}{c}-5.49 \\
(-0.76) \\
\end{array}$ & $\begin{array}{l}-1.05^{*} \\
(-2.10)\end{array}$ \\
\hline Inflation (annual) & $\begin{array}{c}0.77 \\
(1.55) \\
\end{array}$ & $\begin{array}{c}0.56 \\
(1.20) \\
\end{array}$ & $\begin{array}{c}0.65 \\
(1.41)\end{array}$ & $\begin{array}{c}0.59 \\
(1.29) \\
\end{array}$ & $\begin{array}{c}0.77 \\
(1.81) \\
\end{array}$ & \\
\hline Unemployment (annual) & $\begin{array}{c}1.83 \\
(1.13) \\
\end{array}$ & $\begin{array}{c}1.40 \\
(0.94) \\
\end{array}$ & $\begin{array}{c}1.05 \\
(1.18) \\
\end{array}$ & $\begin{array}{c}1.02 \\
(1.12)\end{array}$ & $\begin{array}{l}1.84^{*} \\
(2.00)\end{array}$ & \\
\hline GDP per capita (annual) & $\begin{array}{c}-0.11 \\
(-0.39)\end{array}$ & $\begin{array}{c}-0.02 \\
(-0.08)\end{array}$ & $\begin{array}{c}-0.16 \\
(-0.61)\end{array}$ & $\begin{array}{c}-0.12 \\
(-0.46)\end{array}$ & $\begin{array}{c}-0.16 \\
(-0.60) \\
\end{array}$ & \\
\hline Dummy 1994-1999 & & & & & $\begin{array}{c}6.58 \\
(0.65) \\
\end{array}$ & \\
\hline Dummy $2000-2003$ & & & & & $\begin{array}{l}7.10 \\
(0.60) \\
\end{array}$ & \\
\hline Dummy 2004-2008 & & & & & $\begin{array}{l}15.79 \\
(1.42) \\
\end{array}$ & \\
\hline Constant & $\begin{array}{l}15.37 \\
(1.63) \\
\end{array}$ & $\begin{array}{l}17.76 \\
(1.82) \\
\end{array}$ & $\begin{array}{l}13.55 \\
(1.72) \\
\end{array}$ & $\begin{array}{r}15.00 \\
(1.78) \\
\end{array}$ & $\begin{array}{c}-4.28 \\
(-0.42) \\
\end{array}$ & $\begin{array}{l}7.55 \\
(1.59) \\
\end{array}$ \\
\hline Log Likelihood & -40.61 & -42.35 & -45.09 & -46.10 & -44.31 & -51.66 \\
\hline $\mathrm{LR}$ & 27.62 & 28.43 & 26.48 & 23.31 & 31.07 & 17.01 \\
\hline Number of Observations & 89 & 89 & 95 & 95 & 97 & 97 \\
\hline
\end{tabular}

The variable petitioner is a KMT supporter has the expected negative sign but it is not statistically significant, except for two regressions (none of 
the interaction terms is statistically significant). Percentage of the DPP in the Legislative Yuan has the unexpected negative sign and is statistically significant for most specifications except for two. These two results suggest again that the attitudinal model does not capture the patterns of dissent in the Council; in fact, it seems that there was more dissent during the transition (while the Council was dominated by KMT Presidents' appointees) and less once Taiwan's democracy was more robust (when the Council was no longer dominated by KMT Presidents' appointees). The attributes of the cases, the political nature of the petitioner, and the particular composition of the Council seem to have no impact on the dissent rate. Only the political cycle from transition to more consolidated democracy, as measured by the percentage of the DPP in the Legislative Yuan, seems to matter. ${ }^{103}$ The regression analysis confirms the descriptive statistics of Table 2 . The negative coefficient for female (more women in the Council decreases the likelihood of dissent) is robust and statistically significant in three specifications. However, given the small number of female Justices in the court (see Table 1), we do not emphasize this statistical result.

\section{B. Voting for Constitutionality}

We turn now to the individual votes of each Taiwanese Grand Justice. We have a total of 1357 observations, 612 for constitutionality and the remaining 745 for unconstitutionality. An exploratory quantitative analysis is provided by Table Four. We can see that the Justices appointed by President Chiang vote in a disproportional way for unconstitutionality when the petitioner is associated with the KMT (hence the decision favors the KMT interests). The results are reversed, though, when the Justices are nominated by the following two Presidents, with particular emphasis for those appointed by KMT President Lee. This descriptive analysis provides preliminary evidence that the Justices appointed by KMT President Chiang (before the transition started) have different behavior from that of the Justices appointed by KMT President Lee and DPP President Chen.

${ }^{103}$ The economic control variables, unemployment and inflation, have the expected sign (positive coefficient) but they are not statistically significant. 
TABLE 4

FAVORING KMT INTERESTS

\begin{tabular}{|c|c|c|c|c|c|c|}
\hline & $\begin{array}{l}\text { Vote for } \\
\text { Constituti } \\
\text { onality } \\
\text { when } \\
\text { KMT is } \\
\text { Petitioner }\end{array}$ & $\begin{array}{l}\text { Vote for } \\
\text { Unconstit } \\
\text { utionality } \\
\text { when } \\
\text { KMT is } \\
\text { Petitioner }\end{array}$ & $\begin{array}{c}\text { Vote for } \\
\text { Constituti } \\
\text { onality } \\
\text { when } \\
\text { KMT is } \\
\text { not } \\
\text { Petitioner }\end{array}$ & $\begin{array}{l}\text { Vote for } \\
\text { Unconstit } \\
\text { utionality } \\
\text { when } \\
\text { KMT is } \\
\text { not } \\
\text { Petitioner }\end{array}$ & $\begin{array}{c}\text { Total } \\
\text { Vote for } \\
\text { Constituti } \\
\text { onality }\end{array}$ & $\begin{array}{c}\text { Total } \\
\text { Vote for } \\
\text { Unconstit } \\
\text { utionality }\end{array}$ \\
\hline $\begin{array}{l}\text { Appointed by } \\
\text { President Chiang }\end{array}$ & $\begin{array}{c}33 \\
(23 \%)\end{array}$ & $\begin{array}{c}108 \\
(77 \%)\end{array}$ & $\begin{array}{c}116 \\
(64 \%)\end{array}$ & $\begin{array}{c}67 \\
(36 \%)\end{array}$ & 149 & 175 \\
\hline $\begin{array}{l}\text { Appointed by } \\
\text { President Lee }\end{array}$ & $\begin{array}{c}214 \\
(61 \%) \\
\end{array}$ & $\begin{array}{c}137 \\
(39 \%) \\
\end{array}$ & $\begin{array}{c}86 \\
(28 \%)\end{array}$ & $\begin{array}{c}222 \\
(72 \%)\end{array}$ & 300 & 359 \\
\hline $\begin{array}{l}\text { Appointed by } \\
\text { President Chen }\end{array}$ & $\begin{array}{c}54 \\
(52 \%) \\
\end{array}$ & $\begin{array}{c}51 \\
(48 \%) \\
\end{array}$ & $\begin{array}{c}109 \\
(41 \%) \\
\end{array}$ & $\begin{array}{c}160 \\
(59 \%)\end{array}$ & 163 & 211 \\
\hline Total & $\begin{array}{c}301 \\
(50 \%)\end{array}$ & $\begin{array}{c}296 \\
(50 \%)\end{array}$ & $\begin{array}{c}311 \\
(41 \%)\end{array}$ & $\begin{array}{c}449 \\
(59 \%)\end{array}$ & 612 & 745 \\
\hline
\end{tabular}

Source: Taiwanese Constitutional Court, 1985-2007; own calculations.

Testing for statistical significance: Pearson Chi-Square Statistics $=177.66$ (p-value $=0.0$ ); degrees of freedom $=6$.

Our regression analysis takes the explained variable to be a vote for constitutionality (i.e. against the petitioner). The explanatory variables include:

1) Petitioner is a KMT supporter. ${ }^{104}$

2) The Grand Justice is appointed by one of the three Presidents (i.e. Chiang, Lee, and Chen). ${ }^{105}$

3) Interaction terms between the variables concerning which President appointed the Grand Justice and whether the petitioner is a KMT supporter, the interpretation being that a Grand Justice appointed by a given President and confronted with a petition supported by the KMT is more or less likely to vote for constitutionality.

4) Existence of dissent in the court, measured by the dissent rate.

\footnotetext{
${ }^{104}$ As explained earlier, this variable takes value one if the petitioner(s) is mainly a supporter of the KMT and takes a value of zero otherwise. See supra text accompanying note 96.

105 These variables take the value one if the Grand Justice is appointed by President, and a value of zero otherwise. Note that each class is not mutually exclusive due to reappointments and some Grand Justices are appointed by previous Presidents. See supra Table 1; see also supra text accompanying notes $97 \& 100$.
} 
5) Percentage of the DPP in the Legislative Yuan.

6) Timing control variables, including President Lee in power (1988-2000) and time dummies (to control for important changes in 1993 and in 2003, for example).

7) Judicial control variables to capture the attributes of the individual Grand Justices deciding in each particular decision, including gender, age at appointment, previous career, Mainlanders, and reappointment.

8) Case control variables to capture potential particular characteristics of each decision, including specific disputes (mainly between central and regional governments-regional, across different branches of powerbalance of power, and related to the independence of Taiwanindependence), ${ }^{106}$ and duration of making the decision in months.

9) Interaction terms between the different judicial control variables and whether the petitioner is a KMT supporter.

10) Economic control variables, including annual inflation rate, annual unemployment rate, and annual GDP per capita. These variables capture the context under which the court has issued a decision.

The critical variable to test our hypothesis is the interaction term between the variables concerning which President appointed the Grand Justice and whether the petitioner is a KMT supporter. As explained, the interpretation is that a Grand Justice appointed by a given President and confronted with a petition supported by the KMT is more (if appointed by the KMT President) or less (if appointed by the DPP President) likely to vote for unconstitutionality.

If the hypothesis of political allegiance prevails, then the Grand Justices appointed by the KMT Presidents should help KMT petitioners (vote for unconstitutionality) while the opposite should happen to the Grand Justices appointed by DPP Presidents (although probably in a less significant way as the DPP has never controlled the relevant confirming bodies). For appointments by KMT Presidents Chiang and Lee, we should expect a

\footnotetext{
106 This variable takes the value one if it is a specific case as explained and takes a value of zero otherwise.
} 
negative coefficient whereas for appointments by DPP President Chen, we should expect a positive coefficient.

Due to the fact that some explanatory variables are correlated, we have used different specifications as shown in Tables Five and Six. Due to the non-independence of the votes within cases and within decisions (recall that each case might have more than one decision), we have further estimated the logit models correcting for the non-independence, in particular, using clustering on case initially, and then on issue. In addition, we have also added fixed effects per judge in some specifications. 
TABLE 5

LOGIT REGRESSION OF VOTE FOR CONSTTTUTIONALITY $(=1$ YES, $=0$ NO) WITH CLUSTER BY ISSUE [ALL OBSERVATIONS]

\begin{tabular}{|c|c|c|c|c|c|c|}
\hline Coefficients & Logit 1 & Logit 2 & Logit 3 & Logit 4 & Logit 5 & Logit 6 \\
\hline $\begin{array}{l}\text { Appointed by } \\
\text { President Chiang }\end{array}$ & $\begin{array}{c}0.15 \\
(0.40)\end{array}$ & $\begin{array}{c}0.78 \\
(1.78)\end{array}$ & $\begin{array}{c}0.59 \\
(1.29)\end{array}$ & & $\begin{array}{c}0.19 \\
(1.36)\end{array}$ & $\begin{array}{c}0.06 \\
(0.10)\end{array}$ \\
\hline $\begin{array}{l}\text { Appointed by } \\
\text { President Lee }\end{array}$ & $\begin{array}{c}0.35 \\
(1.30)\end{array}$ & $\begin{array}{c}-0.12 \\
(-0.32)\end{array}$ & $\begin{array}{c}-0.22 \\
(-0.56)\end{array}$ & & $\begin{array}{c}-0.01 \\
(-0.09)\end{array}$ & $\begin{array}{c}0.36 \\
(1.03) \\
\end{array}$ \\
\hline $\begin{array}{l}\text { Appointed } \\
\text { by President Chen }\end{array}$ & $\begin{array}{c}-0.32 \\
(-1.20) \\
\end{array}$ & $\begin{array}{c}-0.26 \\
(-0.74) \\
\end{array}$ & $\begin{array}{l}-0.05 \\
(-0.15) \\
\end{array}$ & & $\begin{array}{c}-0.03 \\
(-0.29) \\
\end{array}$ & $\begin{array}{c}-0.30 \\
(-0.94) \\
\end{array}$ \\
\hline $\begin{array}{l}\text { Party Filing is } \\
\text { KMT "Supporter" }\end{array}$ & $\begin{array}{c}-0.11 \\
(-0.25) \\
\end{array}$ & $\begin{array}{c}0.16 \\
(0.28) \\
\end{array}$ & $\begin{array}{c}-0.31 \\
(-0.43)\end{array}$ & $\begin{array}{c}-0.11 \\
(-0.25) \\
\end{array}$ & $\begin{array}{c}-0.18 \\
(-0.39) \\
\end{array}$ & $\begin{array}{c}-0.11 \\
(-0.25) \\
\end{array}$ \\
\hline $\begin{array}{l}\text { Appointed } \\
\text { by President Chiang } \\
\text { \& KMT Petitioner }\end{array}$ & & $\begin{array}{c}-0.96 \\
(-1.73)\end{array}$ & $\begin{array}{l}-1.11^{*} \\
(-2.02)\end{array}$ & & & \\
\hline $\begin{array}{l}\text { Appointed } \\
\text { by President Lee \& } \\
\text { KMT Petitioner }\end{array}$ & & $\begin{array}{l}1.21^{*} \\
(2.20)\end{array}$ & $\begin{array}{l}1.54 * * \\
(2.72)\end{array}$ & & & \\
\hline $\begin{array}{l}\text { Appointed by } \\
\text { President Chen \& } \\
\text { KMT Petitioner }\end{array}$ & & $\begin{array}{l}-0.42 \\
(-1.05)\end{array}$ & $\begin{array}{l}-0.56 \\
(-1.55)\end{array}$ & & & \\
\hline Female & $\begin{array}{c}0.05 \\
(0.45)\end{array}$ & $\begin{array}{c}0.13 \\
(1.10)\end{array}$ & $\begin{array}{c}0.11 \\
(0.95)\end{array}$ & $\begin{array}{c}0.05 \\
(0.45)\end{array}$ & $\begin{array}{c}0.03 \\
(0.32)\end{array}$ & $\begin{array}{c}0.11 \\
(1.00)\end{array}$ \\
\hline Career Magistrate & $\begin{array}{c}-0.11 \\
(-0.76)\end{array}$ & $\begin{array}{c}-0.13 \\
(-0.63)\end{array}$ & $\begin{array}{c}-0.10 \\
(-0.50)\end{array}$ & $\begin{array}{c}-0.11 \\
(-0.76)\end{array}$ & $\begin{array}{c}-0.09 \\
(-0.64) \\
\end{array}$ & $\begin{array}{c}-0.10 \\
(-0.36) \\
\end{array}$ \\
\hline Law Professor & $\begin{array}{c}-0.23 \\
(-1.26)\end{array}$ & $\begin{array}{c}-0.25 \\
(-0.99)\end{array}$ & $\begin{array}{l}-0.21 \\
(-0.82)\end{array}$ & $\begin{array}{c}-0.23 \\
(-1.26) \\
\end{array}$ & $\begin{array}{c}-0.19 \\
(-1.24) \\
\end{array}$ & $\begin{array}{c}-0.34 \\
(-1.10) \\
\end{array}$ \\
\hline Reappointed & $\begin{array}{c}-0.00 \\
(-0.03)\end{array}$ & $\begin{array}{c}0.08 \\
(0.44)\end{array}$ & $\begin{array}{c}0.06 \\
(0.33)\end{array}$ & $\begin{array}{c}-0.00 \\
(-0.03)\end{array}$ & $\begin{array}{c}0.01 \\
(0.16)\end{array}$ & $\begin{array}{c}0.05 \\
(0.57)\end{array}$ \\
\hline $\begin{array}{l}\text { Mainlander } \\
\text { [First \& Second Gen.] }\end{array}$ & $\begin{array}{c}-0.08 \\
(-0.63)\end{array}$ & $\begin{array}{c}-0.02 \\
(-0.12)\end{array}$ & $\begin{array}{c}0.03 \\
(0.21)\end{array}$ & $\begin{array}{c}-0.08 \\
(-0.63)\end{array}$ & $\begin{array}{c}-0.03 \\
(-0.27) \\
\end{array}$ & $\begin{array}{c}-0.05 \\
(-0.45)\end{array}$ \\
\hline $\begin{array}{l}\text { Career Magistrate } \\
\text { \& KMT Petitioner }\end{array}$ & & $\begin{array}{c}-0.35 \\
(-1.15)\end{array}$ & $\begin{array}{c}-0.34 \\
(-1.10) \\
\end{array}$ & & & \\
\hline $\begin{array}{l}\text { Law Professor } \\
\text { \& KMT Petitioner }\end{array}$ & & $\begin{array}{c}-0.53 \\
(-1.52) \\
\end{array}$ & $\begin{array}{c}-0.53 \\
(-1.51) \\
\end{array}$ & & & \\
\hline $\begin{array}{l}\text { Reappointed } \\
\text { \& KMT Petitioner }\end{array}$ & & $\begin{array}{l}0.21 \\
(1.14)\end{array}$ & $\begin{array}{c}0.21 \\
(1.07)\end{array}$ & & & \\
\hline $\begin{array}{l}\text { Mainlander } \\
\text { \& KMT Petitioner }\end{array}$ & & $\begin{array}{l}-0.38 \\
(-1.89)\end{array}$ & $\begin{array}{l}-0.38 \\
(-1.87)\end{array}$ & & & \\
\hline $\begin{array}{l}\text { Duration of Case } \\
\text { in Months }\end{array}$ & $\begin{array}{c}0.01 \\
(0.43)\end{array}$ & $\begin{array}{c}0.01 \\
(0.34)\end{array}$ & $\begin{array}{c}-0.00 \\
(-0.10) \\
\end{array}$ & $\begin{array}{c}0.01 \\
(0.43) \\
\end{array}$ & $\begin{array}{c}0.01 \\
(0.42)\end{array}$ & $\begin{array}{c}0.01 \\
(0.43) \\
\end{array}$ \\
\hline Specific Disputes & $\begin{array}{c}0.35 \\
(0.80)\end{array}$ & $\begin{array}{c}0.39 \\
(0.88)\end{array}$ & & $\begin{array}{c}0.35 \\
(0.80)\end{array}$ & $\begin{array}{c}0.29 \\
(0.66)\end{array}$ & $\begin{array}{c}0.35 \\
(0.80)\end{array}$ \\
\hline $\begin{array}{l}\text { Disputes on Regional } \\
\text { Powers }\end{array}$ & & & $\begin{array}{c}1.63 \\
(1.69)\end{array}$ & & & \\
\hline
\end{tabular}




\begin{tabular}{|c|c|c|c|c|c|c|}
\hline $\begin{array}{l}\text { Disputes on Balance } \\
\text { of Powers }\end{array}$ & & & $\begin{array}{c}0.13 \\
(0.29)\end{array}$ & & & \\
\hline $\begin{array}{l}\text { Disputes on } \\
\text { Independence of } \\
\text { Taiwan }\end{array}$ & & & $\begin{array}{c}0.08 \\
(0.06)\end{array}$ & & & \\
\hline Age at Appointment & $\begin{array}{c}0.00 \\
(0.45)\end{array}$ & $\begin{array}{c}0.02 \\
(1.59)\end{array}$ & $\begin{array}{c}0.01 \\
(1.23)\end{array}$ & $\begin{array}{c}0.00 \\
(0.45)\end{array}$ & $\begin{array}{c}0.00 \\
(0.30)\end{array}$ & $\begin{array}{c}0.00 \\
(0.31) \\
\end{array}$ \\
\hline $\begin{array}{l}\text { President Lee in } \\
\text { Power (1988-2000) }\end{array}$ & $\begin{array}{c}0.58 \\
(0.35)\end{array}$ & $\begin{array}{c}0.30 \\
(0.16)\end{array}$ & $\begin{array}{c}0.33 \\
(0.17)\end{array}$ & $\begin{array}{c}0.58 \\
(0.35)\end{array}$ & & $\begin{array}{c}0.59 \\
(0.35)\end{array}$ \\
\hline $\begin{array}{l}\text { Percentage of DPP in } \\
\text { Legislative Yuan }\end{array}$ & $\begin{array}{c}-0.01 \\
(-0.15)\end{array}$ & $\begin{array}{c}-0.03 \\
(-0.35) \\
\end{array}$ & $\begin{array}{c}-0 . \overline{04} \\
(-0.43)\end{array}$ & $\begin{array}{c}-0.01 \\
(-0.15)\end{array}$ & $\begin{array}{c}-0.02 \\
(-0.24) \\
\end{array}$ & $\begin{array}{c}-0.01 \\
(-0.13) \\
\end{array}$ \\
\hline Dissent in the Court & $\begin{array}{c}0.33 \\
(0.82) \\
\end{array}$ & $\begin{array}{c}0.14 \\
(0.36) \\
\end{array}$ & $\begin{array}{c}0.05 \\
(0.12) \\
\end{array}$ & $\begin{array}{c}0.33 \\
(0.82) \\
\end{array}$ & $\begin{array}{c}0.25 \\
(0.61) \\
\end{array}$ & $\begin{array}{c}0.33 \\
(0.82) \\
\end{array}$ \\
\hline $\begin{array}{l}\text { N. J. Appointed by } \\
\text { President Chiang \& } \\
\text { Appointed by P. C. }\end{array}$ & & & & $\begin{array}{c}0.00 \\
(0.40)\end{array}$ & & \\
\hline $\begin{array}{l}\text { N. J. Appointed by } \\
\text { President Lee \& } \\
\text { Appointed by P. Lee }\end{array}$ & & & & $\begin{array}{c}0.00 \\
(1.30)\end{array}$ & & \\
\hline $\begin{array}{l}\text { N. J. Appointed by } \\
\text { President Chen \& } \\
\text { Appointed by P. Chen }\end{array}$ & & & & $\begin{array}{c}-0.00 \\
(-1.20)\end{array}$ & & \\
\hline Inflation (annual) & $\begin{array}{c}-0.30 \\
(-1.00) \\
\end{array}$ & $\begin{array}{c}-0.33 \\
(-1.06) \\
\end{array}$ & $\begin{array}{c}-0.40 \\
(-1.25) \\
\end{array}$ & $\begin{array}{c}-0.30 \\
(-1.00) \\
\end{array}$ & $\begin{array}{c}-0.23 \\
(-0.72) \\
\end{array}$ & $\begin{array}{c}-0.30 \\
(-1.00) \\
\end{array}$ \\
\hline $\begin{array}{l}\text { Unemployment } \\
\text { (annual) }\end{array}$ & $\begin{array}{c}-0.36 \\
(-0.53)\end{array}$ & $\begin{array}{c}-0.41 \\
(-0.54)\end{array}$ & $\begin{array}{c}-0.67 \\
(-0.89)\end{array}$ & $\begin{array}{c}-0.36 \\
(-0.53)\end{array}$ & $\begin{array}{c}-0.47 \\
(-0.56)\end{array}$ & $\begin{array}{c}-0.36 \\
(-0.53)\end{array}$ \\
\hline $\begin{array}{l}\text { GDP per capita } \\
\text { (annual) }\end{array}$ & $\begin{array}{c}-0.09 \\
(-0.57)\end{array}$ & $\begin{array}{c}-0.09 \\
(-0.54)\end{array}$ & $\begin{array}{c}-0.19 \\
(-1.10)\end{array}$ & $\begin{array}{c}-0.09 \\
(-0.57)\end{array}$ & $\begin{array}{c}-0.05 \\
(-0.30)\end{array}$ & $\begin{array}{c}-0.09 \\
(-0.57)\end{array}$ \\
\hline Dummy 1994-1999 & & & & & $\begin{array}{c}0.66 \\
(0.79) \\
\end{array}$ & \\
\hline Dummy $2000-2003$ & & & & & $\begin{array}{c}1.04 \\
(0.37) \\
\end{array}$ & \\
\hline Dummy 2004-2008 & & & & & $\begin{array}{c}-0.23 \\
(-0.09) \\
\end{array}$ & \\
\hline Justice Shieh & & & & & & $\begin{array}{r}-0.09 \\
(-0.39) \\
\end{array}$ \\
\hline Justice Wung & & & & & & $\begin{array}{r}0.08 \\
(0.15) \\
\end{array}$ \\
\hline Justice Lin & & & & & & $\begin{array}{l}-0.25 \\
(-1.09) \\
\end{array}$ \\
\hline
\end{tabular}


VOL. 20 No. 1

\begin{tabular}{|c|c|c|c|c|c|c|}
\hline Justice Wang & & & & & & $\begin{array}{c}-0.08 \\
(-0.22) \\
\end{array}$ \\
\hline Justice Liu & & & & & & $\begin{array}{c}0.11 \\
(0.23)\end{array}$ \\
\hline Justice Wu & & & & & & $\begin{array}{c}-0.09 \\
(-0.21)\end{array}$ \\
\hline Justice Tseng & & & & & & $\begin{array}{r}-0.30 \\
(-1.61) \\
\end{array}$ \\
\hline Justice Su & & & & & & $\begin{array}{c}0.40 \\
(1.70)\end{array}$ \\
\hline Constant & $\begin{array}{c}1.45 \\
(0.29)\end{array}$ & $\begin{array}{c}1.66 \\
(0.31)\end{array}$ & $\begin{array}{c}3.86 \\
(0.72)\end{array}$ & $\begin{array}{c}1.45 \\
(0.29)\end{array}$ & $\begin{array}{c}2.03 \\
(0.53)\end{array}$ & $\begin{array}{c}1.51 \\
(0.30)\end{array}$ \\
\hline Log Likelihood & -853.0 & -824.8 & -802.4 & -853.0 & -845.8 & -851.8 \\
\hline LR & 14.85 & 27.84 & 35.38 & 14.85 & 17.73 & 33.68 \\
\hline $\begin{array}{l}\text { Number of } \\
\text { Observations }\end{array}$ & 1357 & 1355 & 1355 & 1357 & 1357 & 1357 \\
\hline $\begin{array}{l}\text { Sensitivity Analysis: } \\
\text { Corrected Classified }\end{array}$ & $64.5 \%$ & $67.0 \%$ & $70.0 \%$ & $64.5 \%$ & $64.6 \%$ & $64.0 \%$ \\
\hline
\end{tabular}

Robust $\mathrm{z}$ statistics in parentheses

${ }^{* * *} \mathrm{p}<0.001,{ }^{* *} \mathrm{p}<0.01,{ }^{*} \mathrm{p}<0.05$ 
TABLE 6

LOGIT REGRESSION OF VOTE FOR CONSTITUTIONALITY ( $=1$ YES, $=0$ NO) WITH CLUSTER By CASE [ALL OBSERVATIONS]

\begin{tabular}{|c|c|c|c|c|c|c|}
\hline Coefficients & Logit 1 & Logit 2 & Logit 3 & Logit 4 & Logit 5 & Logit 6 \\
\hline $\begin{array}{l}\text { Appointed } \\
\text { by President Chiang }\end{array}$ & $\begin{array}{l}0.15 \\
(0.42)\end{array}$ & $\begin{array}{c}0.78 \\
(1.86)\end{array}$ & $\begin{array}{c}0.59 \\
(1.34) \\
\end{array}$ & & $\begin{array}{c}0.19 \\
(1.44)\end{array}$ & $\begin{array}{c}0.06 \\
(0.10) \\
\end{array}$ \\
\hline $\begin{array}{l}\text { Appointed } \\
\text { by President Lee }\end{array}$ & $\begin{array}{c}0.35 \\
(1.42)\end{array}$ & $\begin{array}{c}-0.12 \\
(-0.33)\end{array}$ & $\begin{array}{l}-0.22 \\
(-0.58)\end{array}$ & & $\begin{array}{c}-0.01 \\
(-0.09)\end{array}$ & $\begin{array}{c}0.36 \\
(1.09)\end{array}$ \\
\hline $\begin{array}{l}\text { Appointed } \\
\text { by President Chen }\end{array}$ & $\begin{array}{c}-0.32 \\
(-1.25) \\
\end{array}$ & $\begin{array}{c}-0.26 \\
(-0.76)\end{array}$ & $\begin{array}{l}-0.05 \\
(-0.16) \\
\end{array}$ & & $\begin{array}{c}-0.03 \\
(-0.28) \\
\end{array}$ & $\begin{array}{c}-0.30 \\
(-0.97) \\
\end{array}$ \\
\hline $\begin{array}{l}\text { Party Filing is } \\
\text { KMT "Supporter" }\end{array}$ & $\begin{array}{c}-0.11 \\
(-0.25)\end{array}$ & $\begin{array}{c}0.16 \\
(0.28) \\
\end{array}$ & $\begin{array}{c}-0.31 \\
(-0.43) \\
\end{array}$ & $\begin{array}{c}-0.11 \\
(-0.25)\end{array}$ & $\begin{array}{c}-0.18 \\
(-0.40) \\
\end{array}$ & $\begin{array}{c}-0.11 \\
(-0.25) \\
\end{array}$ \\
\hline $\begin{array}{l}\text { Appointed by President } \\
\text { Chiang \& KMT } \\
\text { Petitioner }\end{array}$ & & $\begin{array}{c}-0.96 \\
(-1.81)\end{array}$ & $\begin{array}{l}-1.11^{*} \\
(-2.07)\end{array}$ & & & \\
\hline $\begin{array}{l}\text { Appointed by President } \\
\text { Lee \& KMT Petitioner }\end{array}$ & & $\begin{array}{l}1.21^{*} \\
(2.35)\end{array}$ & $\begin{array}{l}1.54^{* *} \\
(2.80)\end{array}$ & & & \\
\hline $\begin{array}{l}\text { Appointed by President } \\
\text { Chen \& KMT Petitioner }\end{array}$ & & $\begin{array}{c}-0.42 \\
(-1.07)\end{array}$ & $\begin{array}{c}-0.56 \\
(-1.58)\end{array}$ & & & \\
\hline Female & $\begin{array}{c}0.05 \\
(0.56) \\
\end{array}$ & $\begin{array}{c}0.13 \\
(1.32)\end{array}$ & $\begin{array}{c}0.11 \\
(1.17) \\
\end{array}$ & $\begin{array}{c}0.05 \\
(0.56)\end{array}$ & $\begin{array}{c}0.03 \\
(0.41) \\
\end{array}$ & $\begin{array}{c}0.11 \\
(1.32) \\
\end{array}$ \\
\hline Career Magistrate & $\begin{array}{c}-0.11 \\
(-0.84)\end{array}$ & $\begin{array}{c}-0.13 \\
(-0.65)\end{array}$ & $\begin{array}{c}-0.10 \\
(-0.50) \\
\end{array}$ & $\begin{array}{c}-0.11 \\
(-0.84)\end{array}$ & $\begin{array}{c}-0.09 \\
(-0.65) \\
\end{array}$ & $\begin{array}{c}-0.10 \\
(-0.37) \\
\end{array}$ \\
\hline Law Professor & $\begin{array}{c}-0.23 \\
(-1.37) \\
\end{array}$ & $\begin{array}{c}-0.25 \\
(-1.04)\end{array}$ & $\begin{array}{c}-0.21 \\
(-0.86)\end{array}$ & $\begin{array}{c}-0.23 \\
(-1.37)\end{array}$ & $\begin{array}{c}-0.19 \\
(-1.27)\end{array}$ & $\begin{array}{c}-0.34 \\
(-1.12) \\
\end{array}$ \\
\hline Reappointed & $\begin{array}{c}-0.00 \\
(-0.03) \\
\end{array}$ & $\begin{array}{c}0.08 \\
(0.44) \\
\end{array}$ & $\begin{array}{c}0.06 \\
(0.33) \\
\end{array}$ & $\begin{array}{c}-0.00 \\
(-0.03) \\
\end{array}$ & $\begin{array}{c}0.01 \\
(0.17) \\
\end{array}$ & $\begin{array}{c}0.05 \\
(0.59) \\
\end{array}$ \\
\hline $\begin{array}{l}\text { Mainlander } \\
\text { [First \& Second Gen.] }\end{array}$ & $\begin{array}{c}-0.08 \\
(-0.62) \\
\end{array}$ & $\begin{array}{c}-0.02 \\
(-0.12) \\
\end{array}$ & $\begin{array}{c}0.03 \\
(0.20) \\
\end{array}$ & $\begin{array}{c}-0.08 \\
(-0.62)\end{array}$ & $\begin{array}{c}-0.03 \\
(-0.25)\end{array}$ & $\begin{array}{c}-0.05 \\
(-0.42) \\
\end{array}$ \\
\hline $\begin{array}{l}\text { Career Magistrate } \\
\text { \& KMT Petitioner }\end{array}$ & & $\begin{array}{c}-0.35 \\
(-1.17) \\
\end{array}$ & $\begin{array}{c}-0.34 \\
(-1.11) \\
\end{array}$ & & & \\
\hline $\begin{array}{l}\text { Law Professor } \\
\text { \& KMT Petitioner }\end{array}$ & & $\begin{array}{c}-0.53 \\
(-1.60) \\
\end{array}$ & $\begin{array}{c}-0.53 \\
(-1.58) \\
\end{array}$ & & & \\
\hline $\begin{array}{l}\text { Reappointed } \\
\text { \& KMT Petitioner }\end{array}$ & & $\begin{array}{c}0.21 \\
(1.12)\end{array}$ & $\begin{array}{c}0.21 \\
(1.05) \\
\end{array}$ & & & \\
\hline $\begin{array}{l}\text { Mainlander } \\
\text { \& KMT Petitioner }\end{array}$ & & $\begin{array}{c}-0.38 \\
(-1.84) \\
\end{array}$ & $\begin{array}{c}-0.38 \\
(-1.79) \\
\end{array}$ & & & \\
\hline $\begin{array}{l}\text { Duration of Case } \\
\text { in Months }\end{array}$ & $\begin{array}{c}0.01 \\
(0.48)\end{array}$ & $\begin{array}{c}0.01 \\
(0.39) \\
\end{array}$ & $\begin{array}{c}-0.00 \\
(-0.11) \\
\end{array}$ & $\begin{array}{c}0.01 \\
(0.48) \\
\end{array}$ & $\begin{array}{c}0.01 \\
(0.49)\end{array}$ & $\begin{array}{c}0.01 \\
(0.49) \\
\end{array}$ \\
\hline Specific Disputes & $\begin{array}{c}0.35 \\
(0.72) \\
\end{array}$ & $\begin{array}{c}0.39 \\
(0.78) \\
\end{array}$ & & $\begin{array}{c}0.35 \\
(0.72) \\
\end{array}$ & $\begin{array}{r}0.29 \\
(0.59) \\
\end{array}$ & $\begin{array}{r}0.35 \\
(0.72) \\
\end{array}$ \\
\hline $\begin{array}{l}\text { Disputes on Regional } \\
\text { Powers }\end{array}$ & & & $\begin{array}{c}1.63 \\
(1.72) \\
\end{array}$ & & & \\
\hline
\end{tabular}


VoL. 20 No. 1

\begin{tabular}{|c|c|c|c|c|c|c|}
\hline $\begin{array}{l}\text { Disputes on Balance of } \\
\text { Powers }\end{array}$ & & & $\begin{array}{c}0.13 \\
(0.26)\end{array}$ & & & \\
\hline $\begin{array}{l}\text { Disputes on } \\
\text { Independence of Taiwan }\end{array}$ & & & $\begin{array}{c}0.08 \\
(0.06)\end{array}$ & & & \\
\hline Age at Appointment & $\begin{array}{c}0.00 \\
(0.50)\end{array}$ & $\begin{array}{c}0.02 \\
(1.62)\end{array}$ & $\begin{array}{c}0.01 \\
(1.24)\end{array}$ & $\begin{array}{c}0.00 \\
(0.50) \\
\end{array}$ & $\begin{array}{c}0.00 \\
(0.30)\end{array}$ & $\begin{array}{c}0.00 \\
(0.33) \\
\end{array}$ \\
\hline $\begin{array}{l}\text { President Lee in Power } \\
(1988-2000)\end{array}$ & $\begin{array}{c}0.58 \\
(0.37) \\
\end{array}$ & $\begin{array}{c}0.30 \\
(0.17) \\
\end{array}$ & $\begin{array}{c}0.33 \\
(0.19) \\
\end{array}$ & $\begin{array}{c}0.58 \\
(0.37) \\
\end{array}$ & & $\begin{array}{c}0.59 \\
(0.38) \\
\end{array}$ \\
\hline $\begin{array}{l}\text { Percentage of DPP in } \\
\text { Legislative Yuan }\end{array}$ & $\begin{array}{c}-0.01 \\
(-0.17)\end{array}$ & $\begin{array}{c}-0.03 \\
(-0.42)\end{array}$ & $\begin{array}{c}-0.04 \\
(-0.54)\end{array}$ & $\begin{array}{c}-0.01 \\
(-0.17)\end{array}$ & $\begin{array}{c}-0.02 \\
(-0.29) \\
\end{array}$ & $\begin{array}{c}-0.01 \\
(-0.16)\end{array}$ \\
\hline Dissent in the Court & $\begin{array}{c}0.33 \\
(0.84) \\
\end{array}$ & $\begin{array}{c}0.14 \\
(0.37)\end{array}$ & $\begin{array}{c}0.05 \\
(0.12) \\
\end{array}$ & $\begin{array}{c}0.33 \\
(0.84)\end{array}$ & $\begin{array}{r}0.25 \\
(0.63) \\
\end{array}$ & $\begin{array}{c}0.33 \\
(0.84) \\
\end{array}$ \\
\hline $\begin{array}{l}\text { N. J. Appointed by } \\
\text { President Chiang \& } \\
\text { Appointed by P. C. }\end{array}$ & & & & $\begin{array}{c}0.00 \\
(0.42)\end{array}$ & & \\
\hline $\begin{array}{l}\text { N. J. Appointed by } \\
\text { President Lee \& } \\
\text { Appointed by P. Lee }\end{array}$ & & & & $\begin{array}{c}0.00 \\
(1.42)\end{array}$ & & \\
\hline $\begin{array}{l}\text { N. J. Appointed by } \\
\text { President Chen \& } \\
\text { Appointed by P. Chen }\end{array}$ & & & & $\begin{array}{l}-0.00 \\
(-1.25)\end{array}$ & & \\
\hline Inflation (annual) & $\begin{array}{c}-0.30 \\
(-1.08) \\
\end{array}$ & $\begin{array}{c}-0.33 \\
(-1.16) \\
\end{array}$ & $\begin{array}{l}-0.40 \\
(-1.35) \\
\end{array}$ & $\begin{array}{c}-0.30 \\
(-1.08) \\
\end{array}$ & $\begin{array}{c}-0.23 \\
(-0.77) \\
\end{array}$ & $\begin{array}{c}-0.30 \\
(-1.08) \\
\end{array}$ \\
\hline Unemployment (annual) & $\begin{array}{c}-0.36 \\
(-0.57) \\
\end{array}$ & $\begin{array}{c}-0.41 \\
(-0.58) \\
\end{array}$ & $\begin{array}{c}-0.67 \\
(-0.98) \\
\end{array}$ & $\begin{array}{c}-0.36 \\
(-0.57) \\
\end{array}$ & $\begin{array}{c}-0.47 \\
(-0.58) \\
\end{array}$ & $\begin{array}{c}-0.36 \\
(-0.57) \\
\end{array}$ \\
\hline GDP per capita (annual) & $\begin{array}{c}-0.09 \\
(-0.59)\end{array}$ & $\begin{array}{c}-0.09 \\
(-0.55)\end{array}$ & $\begin{array}{l}-0.19 \\
(-1.14)\end{array}$ & $\begin{array}{c}-0.09 \\
(-0.59)\end{array}$ & $\begin{array}{l}-0.05 \\
(-0.31)\end{array}$ & $\begin{array}{c}-0.09 \\
(-0.59)\end{array}$ \\
\hline Dummy 1994-1999 & & & & & $\begin{array}{c}0.66 \\
(0.83)\end{array}$ & \\
\hline Dummy 2000-2003 & & & & & $\begin{array}{c}1.04 \\
(0.38) \\
\end{array}$ & \\
\hline Dummy 2004-2008 & & & & & $\begin{array}{c}-0.23 \\
(-0.10) \\
\end{array}$ & \\
\hline Justice Shieh & & & & & & $\begin{array}{c}-0.09 \\
(-0.36) \\
\end{array}$ \\
\hline Justice Wung & & & & & & $\begin{array}{c}0.08 \\
(0.15) \\
\end{array}$ \\
\hline Justice Lin & & & & & & $\begin{array}{c}-0.25 \\
(-1.02) \\
\end{array}$ \\
\hline Justice Wang & & & & & & $\begin{array}{c}-0.08 \\
(-0.23) \\
\end{array}$ \\
\hline Justice Liu & & & & & & $\begin{array}{c}0.11 \\
(0.24)\end{array}$ \\
\hline Justice Wu & & & & & & $\begin{array}{c}-0.09 \\
(-0.22)\end{array}$ \\
\hline
\end{tabular}




\begin{tabular}{lcccccc}
\hline Justice Tseng & & & & & & $\begin{array}{c}-0.30 \\
(-1.63)\end{array}$ \\
\hline Justice Su & & & & & $\begin{array}{c}0.40 \\
(1.63)\end{array}$ \\
& 1.45 & 1.66 & 3.86 & 1.45 & 2.03 & 1.51 \\
Constant & $(0.32)$ & $(0.35)$ & $(0.82)$ & $(0.32)$ & $(0.61)$ & $(0.34)$ \\
\hline Log Likelihood & -853.0 & -824.8 & -802.4 & -853.0 & -845.8 & -851.8 \\
\hline LR & 37.04 & 56.57 & 59.85 & 37.04 & 45.59 & 72.84 \\
\hline Number of Observations & 1357 & 1355 & 1355 & 1357 & 1357 & 1357 \\
\hline Sensitivity Analysis: & $64.5 \%$ & $67.0 \%$ & $70.0 \%$ & $64.5 \%$ & $64.6 \%$ & $64.0 \%$ \\
Corrected Classified & & & & & & \\
\hline
\end{tabular}

Robust $\mathrm{z}$ statistics in parentheses

*** $\mathrm{p}<0.001,{ }^{* *} \mathrm{p}<0.01,{ }^{*} \mathrm{p}<0.05$

As can be seen from Tables Five and Six, only the interaction terms are statistically significant. As to other variables, the vote for constitutionality seems to be random and unexplained by them. The interaction terms do not have the expected signs according to our political allegiance hypothesis, except for those Justices appointed by President Chiang. Nevertheless, the coefficients for those appointed by President Chen are not statistically significant (which might indicate our reminder of the fact that DPP has never dominated the Legislative Yuan). The conclusion seems to be that the Grand Justices who were appointed before the democratization tended to favor KMT interests. However, during the transition, the Grand Justices appointed by KMT President Lee had other concerns rather than favoring the interests of the KMT. As to those appointed by President Chen, nothing can be said given the weak statistical results. These econometric results largely confirm the descriptive statistics of Table Four. ${ }^{107}$

\section{DISCUSSION OF RESULTS}

The empirical results do not strongly support the attitudinal model, in particular for those Justices appointed by President Lee. Dissent seems to be higher during this period, and consensus seems more prevalent when the

\footnotetext{
${ }^{107}$ In order to further support our analysis, we have conducted a similar econometric exercise treating reappointed Justices as "new" Justices (in other words, rather than forty-four Grand Justices, we now consider fifty-three Grand Justices). This treatment allows us to exclude the possibility that the previous results are driven by reappointed Justices with overwhelming representation in the sample in certain particular time periods. The results are quite similar to the previous treatment in terms of identifying a statistically significant effect for Grand Justices appointed by President Chiang (negative sign) and President Lee (positive sign).
} 
Justices appointed by DPP President Chen are on the bench. The Justices appointed by KMT President Lee seem to vote against the interests of the KMT more frequently.

In this Part we discuss these results by providing alternative explanations. One immediate explanation is the difficult relationship between President Lee and the KMT itself during President Lee's presidency from 1988 to 2000 . There were several open conflicts between President Lee and other KMT party members. ${ }^{108}$ President Lee was viewed by many in the KMT as a traitor bent on deliberately destroying the party from within, for reasons having to do with his own political goals (e.g. to promote the political status of the native Taiwanese). Since the Justices had various backgrounds and the signal of party preferences was weak and fragmented at that time, it could be that they were serving one KMT faction against the others. The KMT was not a monolithic party in the late 1990s, and thus unsurprisingly the behavior of the Justices reflected these internal tensions and difficulties.

We do not find this explanation very persuasive for the following reasons. First, while encountering the challenges of the opponent factions from time to time, President Lee, (Chairman of the KMT at the time), did not lose domination over the party until it lost the 2000 presidential election. Besides, traditionally presidents of the KMT had enormous power due to its long history of autocracy and paternalism. Hence, it seems unlikely that President Lee would share his power with other defeated factions when appointing Justices. Second, since the opponent factions probably did not have influence on deciding the Justice candidates, it is even more difficult to imagine why the Justices appointed by President Lee would "serve" those factions rather than President Lee.

Third, our empirical analysis shows that the Justices appointed by President Lee disfavored the KMT as a whole, and not only the Lee administration or a specific faction, far before the decisive rupture between the President and the party occurred. Therefore, it does not seem very persuasive that the Justices appointed by President Lee in 1994 intended to

${ }^{108}$ Since Taiwan's strongman politics faded away with Chiang Ching-kuo's death, President Lee could not fully control the KMT as his predecessors could. During his presidency Lee encountered some significant challenges from other factions of the KMT, such as the KMT chair election of 1988 and the presidential elections of 1990,1996 and 2000 . However, Lee won every single battle except the 2000 election. Regarding the 2000 election, most people believe that Lien Chan (the KMT nominee and Lee's successor) lost it mainly because Soong Chu-yu (the PFP candidate, a former KMT member and Lee's right-hand man) also ran for President and separated the KMT supporters dramatically. This significant electoral defeat not only ended the KMT's fifty-five year rule in Taiwan but also openly expelled Lee from the KMT in 2001. Later that same year, Lee founded a new pro-Taiwan independence party called Taiwan Solidarity Union (TSU), which joined the DPP coalition and is still a part of it today. 
represent different voices of the KMT factions even before there was a largescale internal conflict in the party; not to mention that in 1994 it was unforeseeable that the KMT would confront the significant electoral defeat in 2000 that would cause President Lee to lose control over the party. ${ }^{109}$ Finally, our results do not show that judicial background has a strong predictive power concerning the behavior of the Justices. For example, we control for origins (i.e. a Mainlander or a native Taiwanese) but this factor has no statistically significant effect on individual behavior.

A second possible explanation would be that President Lee appointed a moderate coalition of Justices who disfavored the traditional KMT. It is clear that President Lee entertained appointments in a different way than his predecessors given the transition to democracy. But when President Lee was in power, the opposition had limited influence in the Legislative Yuan. Since the transition to democracy was dominated by the KMT until 2000 , there is no reason to think that the KMT president and legislators would agree on appointing a moderate coalition of Justices who would systematically undermine the prevailing interests of the ruling party.

Another possible theory, following the work in other contexts ${ }^{110}$ would be that the Justices appointed by President Lee switched sides in order to preserve their jobs. We could use the so-called strategic defection hypothesis here. However, not only was there no real threat to the survival of the Council (quite the contrary as we have seen previously), but at that time the KMT had kept a dominant position for over fifty years. If we see the behavior of the Justices from the perspective of political survival in an environment with limited tenure, switching sides to become hostile to the long-time dominant party does not seem a compelling strategy.

Our explanation is that, faced with a transition from a KMTdominated political regime to a democracy (with the election of an opposition candidate to the presidency in 2000 and the return of a KMT president in 2008), the Taiwanese Grand Justices needed to assert their independence from the other branches of government and gain credible reputations in order to maximize their influence (i.e. a strategy to promote juristocracy). Thus, they started dissenting more frequently and individually voting against the interests of the KMT. Under this hypothesis, dissent in the Council actually plays a double role. During the political transition,

\footnotetext{
${ }^{109}$ We have run a third robustness check by dividing the appointees of President Lee by those appointed in 1994 and those appointed in 1999 in order to control for any particular circumstances that might have affected the profile of appointees, particularly the emerging open conflict between President Lee and other factions in the KMT after 1996. The regressions do not show any significant differences.

${ }^{110}$ See HelMKE, supra note 12 (discussing Argentina).
} 
dissent is a sign of increasing independence from the KMT tutelage and can develop a solid constitutional review process. But once democracy is more consolidated, dissent becomes a sign of political division in the Council (between pro-KMT Justices and pro-opposition Justices) and may undermine the ability of the Council to achieve judicial supremacy. ${ }^{11}$

There are several possible mechanisms that may explain why dissent increases the reputation and credibility of Council. One possibility is that the Grand Justices either value the reputation of independence itself or consider that it is instrumental in achieving supremacy over other judicial courts. Dissent signals disaffection with the dominant party, thus reinforcing the reputation of independence. Furthermore, given the influence of the KMT in the period and the likely return to power (as indeed happened in 2008), dissent has been a costly signal of independence.

Another possibility is that the Grand Justices appointed by KMT Presidents had a large variance of preferences in terms of judicial outcomes, but were awed by the dominance of this long-time ruling party. In this case, KMT Presidents had little to worry about Justices' personal preferences because the authoritarian nature of the political regime secured the needed unanimity. However, when the Council entered the period of democracy, the Grand Justices dissented more often according to their true preferences. This also provides credibility to the independence of the court since it becomes clear that the ruling party can no longer prevent dissent among its own appointees. In later periods, both parties (KMT and DPP) become more careful with the selection of Grand Justices according to their political interests, and hence reduce the prevalence of dissent.

Our explanation proposes the building of reputation and the securing of legal supremacy as the main explanation for judicial behavior in the transitional period (either because the Justices care about judicial independence or because they believe that it is instrumental in satisfying their individual political goals), but discards the prevalent attitudinal model.

In addition, unlike the strategic defection hypothesis, our explanation relies on a more collective or collegial interpretation of the role of the Council (which seems unlikely in Argentina but also can be found in Chile or in Japan). Part of the argument is that the Justices care about the prestige and the legitimacy of the Council. At the same time, procedure and voting mechanisms reinforce the consolidation of the collegial interests in

111 In a civil law system, where the judicial courts and the production of coherent legal doctrines are particularly unsympathetic to dissents from the bench, a specialized constitutional court will inevitably favor unanimous decisions in order to be regarded as a supreme judicial body. See Garoupa, supra note 65 . 
credibility-building. ${ }^{112}$ Our story proposes the need for achieving legitimacy as the main explanation for judicial behavior in the transition.

\section{CONCLUSION}

This paper presents an empirical study about the Taiwanese constitutional court with respect to judicial behavior. We have tested the hypothesis that judicial behavior is dominated by political allegiance, either because Justices' preferences coincide with the interests of a specific party or because they simply would like to show their loyalty to a specific party. However, our results do not seem to confirm the political allegiance hypothesis.

The Grand Justices appointed by President Chiang (in 1985) seem to promote the interests of the KMT more vehemently than all other Justices. They sat on the bench from the end of the authoritarian regime to the beginning of the transition. The Grand Justices appointed by President Lee (in 1994 and 1999), on the contrary, seem to vote against the interests of the KMT more frequently. They sat on the constitutional court during most of the transitional time.

We have obtained no statistically significant result for the Grand Justices appointed by President Chen (in 2003 and 2007), which might not be surprising if we take into account the fact that they served at the end of the transition and faced a more liberal democracy (while at the same time the DPP did not control the Legislative Yuan). They seem to be less inclined to vote against the interests of the KMT than their predecessors, but this might well be due to the need to keep some reputation for judicial independence (since President Chen was supported by the DPP).

Dissent rates increased during the political transition and seem to have decreased once democracy took root. Our descriptive analysis is supported by the econometric results showing that dissent rates are negatively related to the DPP (traditional opposition to the KMT) role in the Legislative Yuan. The parliamentary gains of the opposition party were stable during the transition and max out once democracy emerged.

Our interpretation is that politics matter in the Taiwanese constitutional court, but not in the conventional government-opposition or left-right dimensions. During the political transition from the authoritarian regime to democracy, the Council of Grand Justices had to liberate itself from the KMT tutelage and establish a solid reputation for judicial independence. As a consequence, Grand Justices appointed by KMT

\footnotetext{
${ }^{112}$ See supra text accompanying note 85 .
} 
Presidents were willing to disfavor the KMT in a more systematic way. Dissent rates went up to signal independence from the KMT. However, as democracy has emerged, dissent rates have gone down. Now, as in many other "Kelsenian" constitutional courts, the Grand Justices need to assert their independence from the other branches of government by establishing consensus and sound legal doctrines. Dissent rates no longer serve the purpose of signaling independence.

We also observe that the appointment process and other features of the Taiwanese constitutional court do not generate party quotas or majority versus minority coalitions as seen in other similar courts. ${ }^{113}$ This might reduce the likelihood of the political allegiance to the appointing President emerging as a solid predictor of Justices' voting behavior. Nevertheless, along with the end of a political transition and the beginning of a more consolidated democracy, we might observe more party politics in the Council of Grand Justices in the near future. ${ }^{114}$

${ }^{113}$ In addition, we did not find any statistically significant correlation between the Justices' career backgrounds as law professors and the increase of dissent, as some Taiwanese legal scholars expected.

${ }^{114}$ In fact, we speculate that the story of Taiwan's constitutional court will be very different in the next decade because of the following factors: (1) the KMT has controlled both the Presidency and more than $70 \%$ of the legislative seats since 2008 (the next elections will not be held until 2012); (2) the DPP is now reduced to comprise less than $30 \%$ of the legislative seats (in this case, they can neither petition for a constitutional interpretation nor vote down any Justice candidate); and (3) KMT President Ma has already appointed five Justices to the bench in 2008 and will have a chance to appoint another seven Justices in 2011. For these reasons, we predict that: (1) the KMT will enhance its political influence in every public sector, including the constitutional court, in the next couple of years; (2) if the DPP and its allies cannot win the general and presidential elections in the next eight years, they might accept a de facto quota system of judicial appointments as this option is better than no representation whatsoever; and (3) the constitutional court will be more cautious when voting against the main interests of the KMT and the appointees of President Ma will likely be very ideologically different from President Chen or even President Lee. 


\section{APPENDIX: CODING CONTROVERSIAL CASES}

We list all the controversial cases as follows, and explain why some Justices' dissenting opinions have been coded as the majority opinions in those Interpretations of the Judicial Yuan ("JYI").

1) Interpretation No. 592: In this case, the majority opinion favors the petitioner, so their votes have been coded as zero (i.e. unconstitutional). As to J2's dissenting, he is also favorable to the petitioner, so his vote has been coded as " 0 " too. But J14 claims this case should be dismissed (unfavorable to the petitioner), so his vote has been coded as one.

2) Interpretation No. 585: Although it is not a unanimous decision, we have not coded J5 and J6's votes otherwise after reviewing their partial dissenting opinions.

3) Interpretation No. 553: The majority and concurring have been coded as one. Meanwhile, since J2's dissenting says this case should be dismissed (also unfavorable to the petitioner), so his vote has been coded as one as well.

4) Interpretation No. 543: In this JYI, the majority declare that the regulations in question do not totally fit in with the Constitution and that they should have been reviewed by the legislators (favorable to the petitioner), so their votes have been coded as zero. As to J28's dissenting, he strongly claims the regulations unconstitutional, so his vote has also been coded as zero.

5) Interpretation No. 520: In this JYI, the majority and concurring have been coded as one (unfavorable to the petitioner, Executive Yuan). Since J26 presents a partial concurring opinion, his vote has been coded as the majority's vote (i.e. one). As to J20, J24 and J28's dissenting opinions, since they all are strongly against the petitioner, their votes have been coded as one.

6) Interpretation No. 485: The majority declare the law in question is constitutional (unfavorable to the petitioners). However, J26's dissenting opinion is also unfavorable to the petitioners (he claims this case should be dismissed), so we have also coded his vote as one. 
7) Interpretation No. 450: The majority favor the petitioners, so their votes have been coded as zero. As to J26's dissenting, since he only disagrees with the reasoning of the majority, not the conclusion (i.e. the holding) of the majority, his vote has been coded as zero too.

8) Interpretation No. 419: On issue 1)— whether Vice President may serve as Premier of the Executive Yuan at the same time-the votes of the majority have been coded as zero (i.e. unconstitutional) because: (1) unlike $\mathrm{J} 20$ and J28's dissenting opinions (coded: zero), the majority does not say this status is obviously unconstitutional, but they declare it is constitutionally inappropriate in the end, and (2) after this JYI released, then Vice President Lien Chan later resigned his post as Premier of the Executive Yuan.

9) Interpretation No. 290: We have coded the majority's votes as one. As to J37 and J40's so-called "dissenting" opinions, since they are actually concurring opinions (they only disagree with the majority's reasoning, not the holding), these two votes have also been coded as one. 